\title{
High-frequency palaeoenvironmental changes on a shallow carbonate platform during a marine transgression (Late Oxfordian, Swiss Jura Mountains)
}

\author{
StÉPHANIE VÉdrine ${ }^{1, *} \&$ ANDrÉ STRASSER ${ }^{1}$
}

Key words: shallow carbonate platform, detailed microfacies analysis, high-resolution sequence stratigraphy, cyclostratigraphy, transgression, Late Jurassic, Switzerland

\begin{abstract}
Based on a well-established bio- and sequence-stratigraphic framework, a narrow time window in the Bimammatum ammonite zone (Late Oxfordian) is investigated in six Swiss Jura sections representing a shallow-water carbonate platform. From the detailed facies and microfacies analysis of oncoid-rich (Hauptmumienbank Member) and ooid-rich (Steinebach Member) limestones, a microfacies classification is established, depositional environments are interpreted, and a depositional model for the Swiss Jura platform is proposed. The sequence- and cyclostratigraphic interpretation has been performed for the transgressive part of the medium-scale sequence Ox6+, independently for each section, with a very high time resolution at the scale of elementary depositional sequences. The good correlation of the elementary and small-scale sequences between the six studied sections and the similar number of elementary sequences in all sections strongly suggest that allocyclic processes were involved in their formation. The hierarchically stacked depositional sequences (small-scale and elementary sequences) result from orbitally controlled sea-level changes with periodicities of 100 and $20 \mathrm{kyr}$, respectively. Thickness variations in the correlated small-scale and elementary sequences imply variable sedimentation rates, probably resulting from differential subsidence due to the activity of tectonic blocks. The tectonically controlled platform morphology contributed significantly to the general pattern of depositional environments and, combined with high-frequency sea-level fluctuations, created a complex facies distribution in time and space on the Swiss Jura carbonate platform.
\end{abstract}

RÉSUMÉ

Basée sur un cadre biostratigraphique et séquentiel bien défini, une fenêtre de temps précise dans la zone d'ammonite à Bimammatum (Oxfordien supérieur) est étudiée dans six coupes du Jura suisse représentant une plate-forme carbonatée peu profonde. A partir de l'analyse détaillée des faciès et des microfaciès des calcaires riches en oncoïdes (membre de Hauptmumienbank) et riche en ooïdes (membre de Steinebach), une classification des microfaciès est établie, les environnements de dépôts sont interprétés et un modèle de dépôt pour la plate-forme du Jura suisse est proposé. L'interprétation séquentielle et cyclostratigraphique a été réalisée pour la partie transgressive de la séquence à moyen-terme Ox6+, indépendamment pour chaque coupe, avec une très haute résolution à l'échelle des séquences de dépôts élémentaires. La bonne corrélation des séquences élémentaires et à court-terme entre les six coupes étudiées et le nombre similaire de séquences élémentaires dans toutes les coupes suggèrent fortement que des processus allocycliques ont joué un rôle dans leur formation. Les séquences de dépôts empilées hiérarchiquement (séquences à court terme et élémentaires) résultent des fluctuations du niveau marin, elles-mêmes contrôlées par les cycles orbitaux avec des périodicités de 100 et $20 \mathrm{ka}$, respectivement. Les variations d'épaisseurs dans les séquences à court terme et élémentaires corrélées impliquent des taux de sédimentation variables, résultant probablement de la subsidence différentielle due à l'activité tectonique des blocs. La morphologie de la plate-forme contrôlée tectoniquement a contribué significativement à la distribution générale des environnements de dépôts et, combinée aux fluctuations de haute fréquence du niveau marin, à une distribution complexe des faciès dans le temps et dans l'espace sur la plate-forme carbonatée du Jura suisse.

\section{Introduction}

A marine transgression is the flooding of land by the sea and is caused by subsidence and/or sea-level rise. Today many coasts experience transgression due to sea-level rise resulting from thermal expansion of the ocean water and from melting of continental ice (IPCC 2007). It is therefore appropriate to study transgressions in the geological past and to evaluate the effects they can have on depositional environments and ecosystems.
Shallow carbonate platform deposits were chosen for investigation due to their high sensitivity to sea-level and climate changes. This study proposes a high-resolution sedimentological analysis of transgressive Late Oxfordian deposits from the Swiss Jura Mountains (northern Switzerland). The studied interval is particular because of the superimposition of a medium-term transgression on a long-term (million-year scale) transgressive trend. This interval thus has the best potential of sediment preservation because the accommodation gain is

${ }^{1}$ Department of Geosciences - Earth Sciences, University of Fribourg, Chemin du Musée 6, 1700 Fribourg, Switzerland.

*Corresponding author: S. Védrine.E-mail: steph_vedrine@yahoo.fr

Present address: 92 rue de Crimée, 75019 Paris, France. 


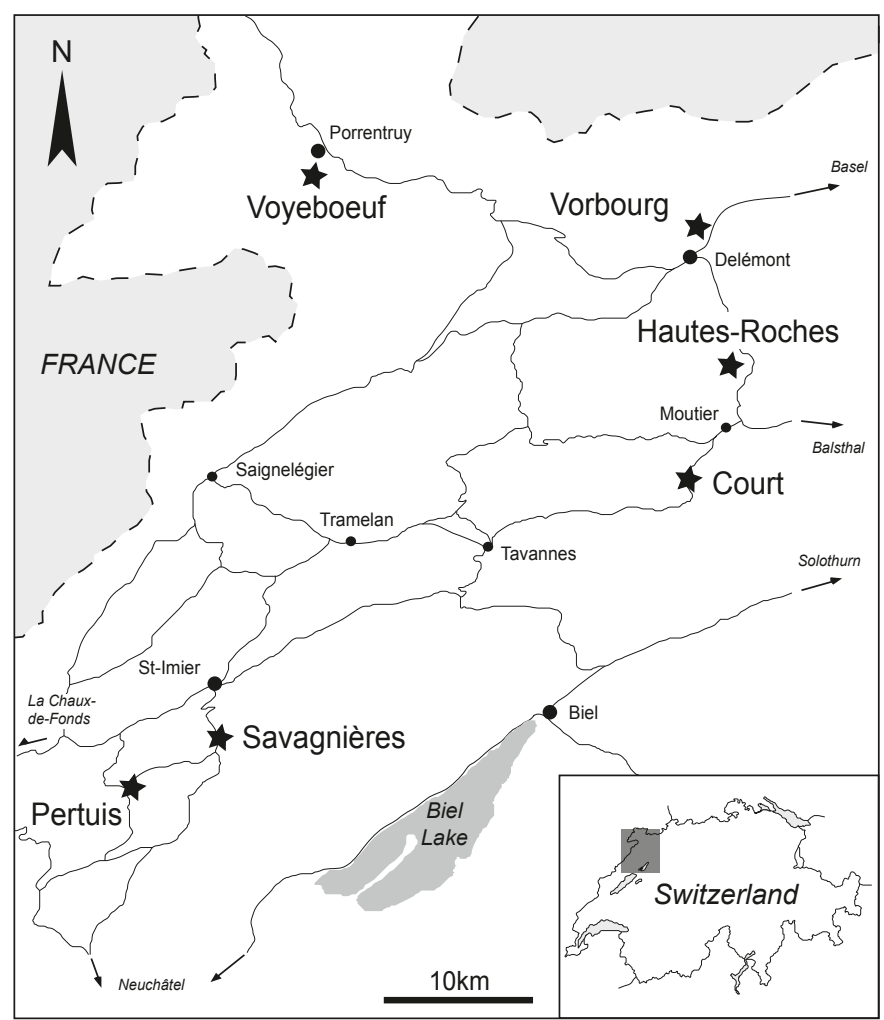

Fig. 1. Geographical position of the six studied sections in the Swiss Jura Mountains. high and allows for a relatively complete sedimentary record. Identification and interpretation of high-frequency palaeoenvironmental changes are based on a detailed field, facies, and microfacies analysis followed by a sequence- and cyclostratigraphic analysis. The latter provides a precise time framework with a resolution of $20 \mathrm{kyr}$, in which the palaeoenvironmental evolution is investigated.

\section{Geography, palaeogeography, and palaeoclimate}

Six sections of shallow-water carbonates have been logged in the Swiss Jura Mountains, within an area between the cities of Porrentruy, Delémont, and La Chaux-de-Fonds (Fig. 1). In Middle and Late Oxfordian times, the palaeolatitude of the Jura platform is estimated between $26^{\circ}$ and $28^{\circ} \mathrm{N}$ (Dercourt et al. 1993; Thierry et al. 2000; Fig. 2). A wide carbonate-dominated platform extended from Aquitaine to Bohemia, including today's French and Swiss Jura Mountains. The Swiss Jura corresponded to a shallow-water carbonate platform with tidal flats, oncoid-rich lagoons, oolitic bars, and coral patch-reefs. Synsedimentary tectonics structured the platform into highs and depressions that shifted their position through time (Allenbach 2001). Erosion of the surrounding crystalline massifs (i.e. Bohemian Massif, Rhenish Massif, Massif Central, London-Brabant Massif; Fig. 2) furnished siliciclastics to the Paris Basin and to the northern Tethyan platform (Gygi 1986; Pittet 1996; Hug 2003).

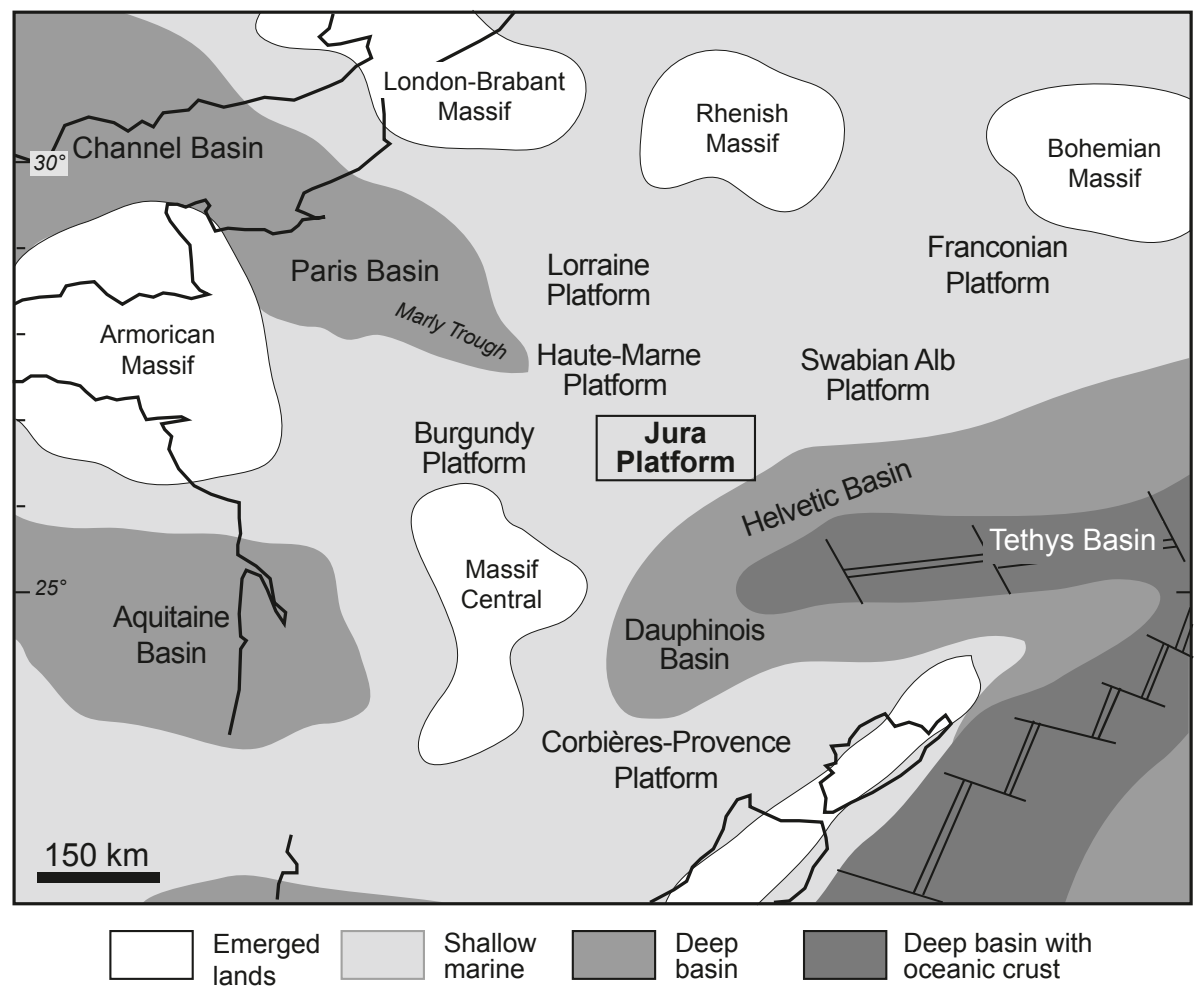

Fig. 2. Palaeogeography of the northern margin of the Alpine Tethys during the Late Oxfordian (modified from Meyer \& Schmidt-Kaler 1990; Ziegler 1988; Thierry et al. 2000). $25^{\circ} \mathrm{N}$ and $30^{\circ} \mathrm{N}$ palaeolatitudes are indicated. The studied area is marked in bold. 
Late Jurassic climate was characterized by a greenhouse period with high atmospheric $\mathrm{CO}_{2}$ levels (e.g., Moore et al. 1992), a monsoonal rainfall pattern (Parrish 1993), warm and humid conditions, and markedly reduced latitudinal temperature gradients with respect to the present day (Hallam 1984,1985; Wignall \& Ruffell 1990). However, there is mounting evidence for cooler climate periods with high-latitude seasonal ice ("cool mode" of Frakes et al. 1992) that were superimposed on this general warmth. Towards the Late Oxfordian, climate became more arid and warmer (Frakes et al. 1992; Abbink et al. 2001). On the Jura platform, this is indicated by generally less siliciclastics and by evaporite pseudomorphs (Hug 2003). This general evolution was modulated by high-frequency climate changes related to orbital (Milankovitch) cycles (Pittet 1996; Dupraz 1999; Hug 2003). These not only controlled siliciclastic input through periodically increased rainfall but also periodic evaporite formation under arid conditions (Hug 2003). Furthermore, they were responsible for low-amplitude sea-level fluctuations that led to the formation of hierarchically stacked depositional sequences (Strasser et al. 1999, 2000; Strasser 2007).

\section{Lithostratigraphy and biostratigraphy}

Stratigraphic studies in the Swiss Jura Mountains began at the beginning of the 1800's (Merian 1821). Facies and lithostratigraphy of the Middle and Late Oxfordian deposits from northern Switzerland have been investigated extensively by, e.g., Ziegler (1962), Bolliger \& Burri (1967, 1970), Gygi (1969, 1992, 1995), and Gygi \& Persoz (1986). Gygi (2000a, b) gives an excellent summary of the history of lithostratigraphic classification in northern Switzerland. The present work focuses on the middle part of the Vellerat Formation composed of the Röschenz Member, the Hauptmumienbank Member and its lateral equivalent, the Steinebach Member (Fig. 3). The Röschenz Member is composed of marls and thin limestone beds whereas the Hauptmumienbank and Steinebach members consist of relatively massive limestone beds. The Hauptmumienbank ("main mummy bed") Member has a typical oncolitic facies while the Steinebach Member features oolites and coral boundstones (Gygi 2000b).

The biostratigraphic framework for the Oxfordian in the Jura Mountains was established using ammonites from platform and epicontinental basin deposits (Enay et al. 1988; Gygi 1995). Dating of platform deposits was improved by mineralostratigraphic correlations (Persoz \& Remane 1976; Gygi \& Persoz 1986). These authors used the vertical distribution of kaolinite and detrital quartz to correlate ammonite-rich basin sections with biostratigraphically less well-constrained sections on the platform. The Hauptmumienbank and Steinebach members are dated of the Hypselum ammonite subzone, equivalent to the Semimammatum and Berrense subzones placed at the beginning of the Bimammatum zone (Gygi \& Persoz 1986; Gygi 2000b; Fig. 3).

\section{Sequence- and cyclostratigraphy}

The marly Röschenz Member represents the relatively shallowest facies in the Oxfordian of the Swiss Jura. These facies,
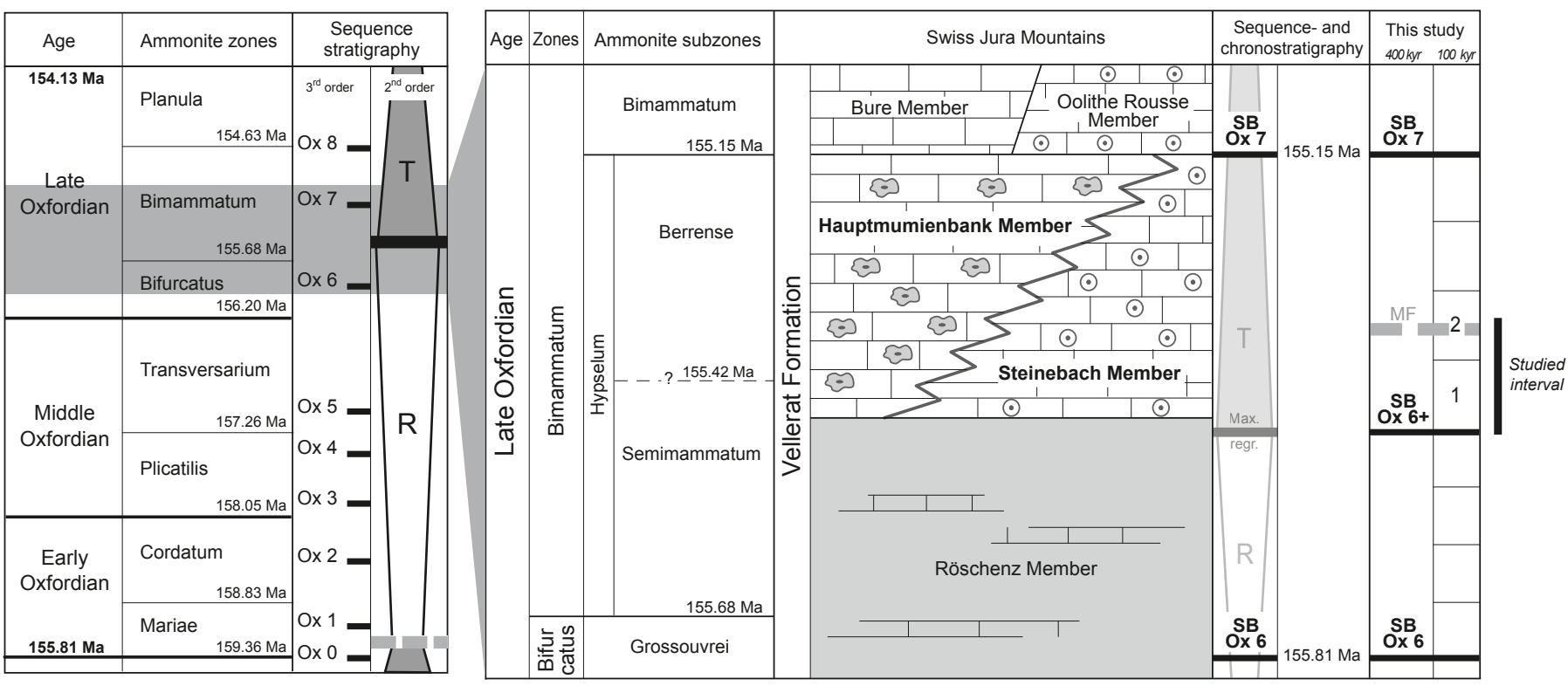

Fig. 3. Stratigraphic position of the Röschenz, Hauptmumienbank and Steinebach members on the Swiss Jura platform. Lithostratigraphy and biostratigraphy after Gygi \& Persoz (1986) and Gygi (1995, 2000b), $2^{\text {nd }}-$ order and $3^{\text {rd }}$-order sequence stratigraphy after Hardenbol et al. (1998) and Strasser et al. (2000). This study investigates with a high time resolution an interval corresponding to one and a half small-scale (100-kyr) sequences, between the medium-scale (400kyr) sequence boundary SB Ox6+ at the top of the Röschenz Member and the medium-scale (400-kyr) maximum flooding MF Ox6+ in the Steinebach and Hauptmumienbank members. SB: sequence boundary; MF: maximum flooding; R: second-order regressive trend; T: second-order transgressive trend. Ages of ammonite subzone boundaries and of sequence boundaries according to Hardenbol et al. (1998). Absolute ages are based on Gradstein et al. (1995). 
particularly the top part of the Röschenz Member, mark the maximum of regression of the second-order sea-level cycle that covers the Oxfordian and the beginning of the Kimmeridgian (Gygi 1995; Hardenbol et al. 1998; Fig. 3). The present study investigates lagoonal deposits that lie between the third-order sequence boundaries (SB) Ox6 and Ox7 defined by Hardenbol et al. (1998) in European basins. In the Swiss Jura Mountains, SB Ox6 is placed within the Röschenz Member and SB Ox7 at the facies change between the Hauptmumienbank Member and the Oolithe Rousse Member (Fig. 3). Between Ox6 and Ox7, an additional major sequence boundary (SB Ox6+) has been identified in the Hypselum subzone (Fig. 3; Hug 2003; Strasser et al. 2005). This sequence boundary coincides with the $2^{\text {nd }}$-order maximum regression according to Hardenbol et al. (1998). Six to eight small-scale depositional sequences, each composed of five elementary sequences, were counted between Ox6 and Ox7 (Hug 2003; Strasser et al. 2005; Strasser 2007; Védrine 2007). Based on the absolute ages given by Gradstein et al. (1995), Hardenbol et al. (1998) date SB Ox6 at 155.81 Ma and SB Ox7 at $155.15 \mathrm{Ma}$ (Fig. 3). This implies a time span of 600 to $700 \mathrm{kyr}$ between these two sequence boundaries. Consequently, it is suggested that a small-scale sequence formed within 75 to $117 \mathrm{kyr}$ and an elementary sequence within 15 to $23 \mathrm{kyr}$. These values coincide well with those of the first orbital eccentricity cycle $(100 \mathrm{kyr})$ and of the precession cycle $(20 \mathrm{kyr}$ in the Oxfordian; Berger et al. 1989). In most Oxfordian sections of the Swiss Jura, elementary, small-scale, and medium-scale sequences display a systematic hierarchical stacking pattern. It has been demonstrated by Pittet (1996) and Hug (2003) that this pattern corresponds to the periodicities of Milankovitch cycles. Especially the small- and medium-scale sequences show clear deepening-shallowing trends of facies evolution and are thus interpreted to have been caused by sea-level fluctuations, which were related to climate changes, themselves controlled by the astronomical parameters of the Earth's orbit. Consequently, the observed depositional sequences are the sedimentological expression of orbital cycles and are attributed to the precession cycle $(20 \mathrm{kyr})$ for the elementary sequences, and to the short- and long-eccentricity cycles (100 kyr and $400 \mathrm{kyr}$ ) for the small- and medium-scale sequences, respectively. In the Middle and Late Oxfordian sedimentary record of the Jura Mountains, 100-kyr and 400-kyr sequences are easily recognized whereas 20-kyr sequences are more difficult to identify (Pittet 1996; Hug 2003). The definition of the medium-scale sequence Ox6+, within which the studied interval occurs, is based on Hug (2003) and Strasser (2007).

\section{Material, definitions, and methods}

Six sections of 7 to 14 meters thick have been logged at a cm scale and densely sampled. Then, a sequence- and cyclostratigraphic analysis was carried out for a high-resolution monitoring of the marine transgression following the Ox6+ sequence boundary (Fig. 4). For the sedimentological analysis, samples were taken at the base, in the middle, and at the top of beds. In total, 300 polished slabs and thin sections, plus 25 washing residues of marls were examined. Analyses of the texture and the semiquantification of skeletal and non-skeletal elements were performed on thin sections and rock slabs. Sequence-stratigraphic interpretations were made separately for each section based on the comprehensive sedimentological analysis of the sections. The methodology is summarized in Strasser et al. (1999). The terminology follows that of the sequence-stratigraphic model of Vail et al. (1977, 1991). A depositional sequence is a succession of genetically related sediments whose facies evolution and/or stacking pattern is repetitive within a section. Depositional sequences are commonly delimited by discontinuity surfaces or intervals of well-marked facies change, indicating an inversion in the trend of environmental change. They are the stratigraphic expression of recurring environmental changes, independent of scale and time. This nomenclature has the advantage of being purely descriptive and not implying any duration as long as the time framework is not known.

\section{Facies and microfacies analysis}

The typical succession of deposits consists of nodular/massive oncolitic limestones with flat or wavy bed surfaces (Hauptmumienbank Member) and/or ooid-rich bars (Steinebach Member) overlying marl-dominated deposits (Röschenz Member). Remarkable surfaces occur in the Vorbourg section (a perforated and oyster-encrusted hardground, indicating sediment starvation - see text below), in the Voyeboeuf section (an intensely bioturbated wavy surface), and in the Savagnières section (a serpulid-rich layer, suggesting reduced salinity; Brasier 1995).

A microfacies classification has been established for the studied platform deposits (Fig. 5). The discriminating criteria are the Dunham classification (texture), the components, the fauna and flora association and diversity, and the abundance of terrigenous particles. These sedimentary characteristics are used to evaluate environmental factors such as energy, salinity, and trophic level (Fig. 6). The rock texture is used to interpret the water energy of the depositional environment. For example, a grainstone texture indicates relatively high-energy conditions while a mudstone texture points to low-energy conditions. The fossil assemblage and diversity inform about water salinity and trophic level. For example, the occurrence of stenohaline organisms (e.g., corals, brachiopods, and echinoderms) with high- to moderate-diversity fauna indicates normal and constant salinity and oligo- to mesotrophic conditions, characterizing open to semi-open environments, whereas charophytes or the association of ostracodes and gastropods (i.e. low diversity fauna) imply low and variable salinity and eutrophic conditions, characterizing more protected environments.

In this work, three types of depositional environments (protected, semi-open, and open) and two types of environmental conditions (semi-restricted and normal-marine) have been defined based on the sedimentary characteristics and the interpreted environmental factors (Figs. 5 and 6). The examined limestones have textures from mudstone to grainstone and are

250 S. Védrine \& A. Strasser 

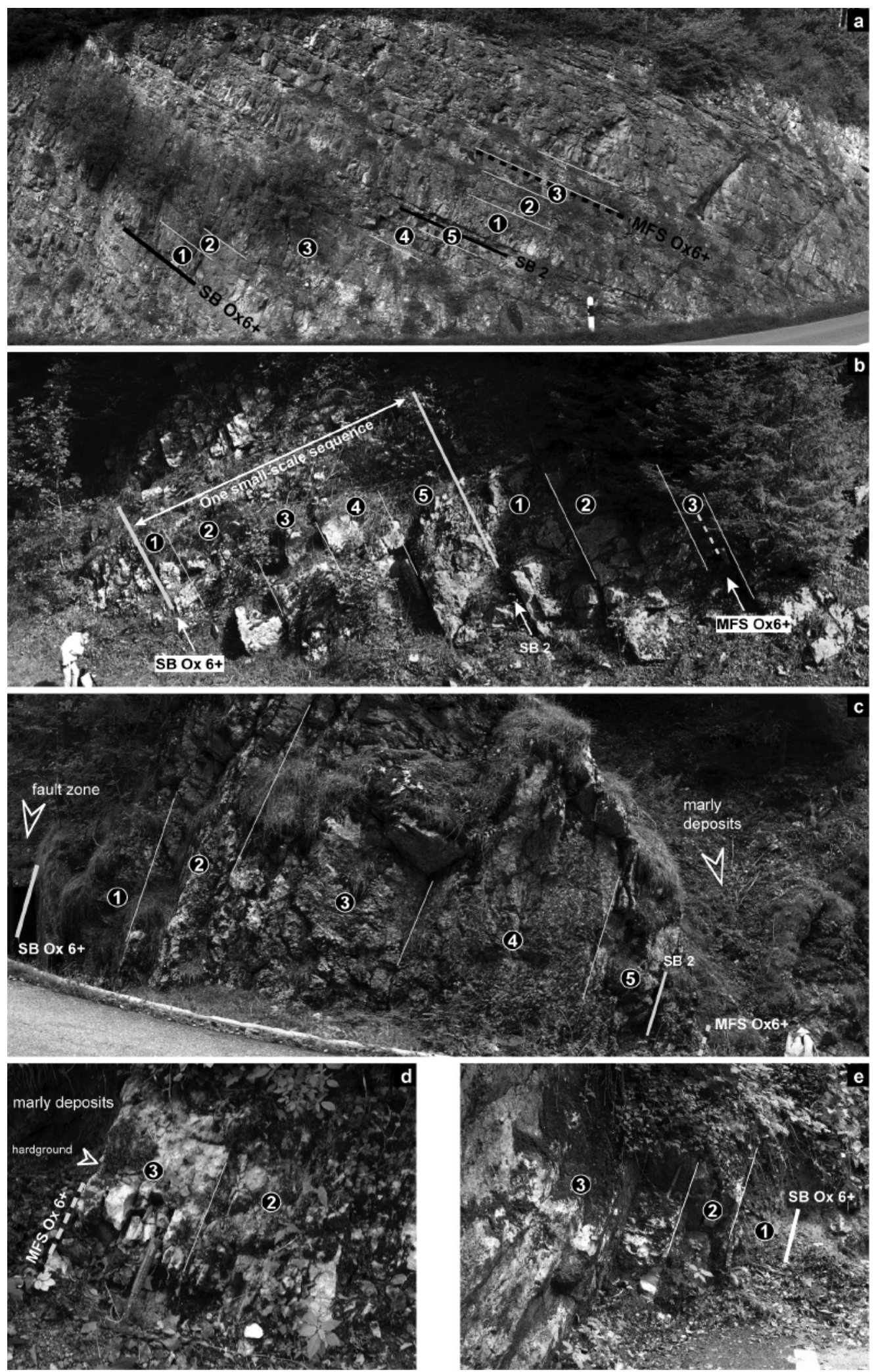

Fig. 4. Examples of sections exposing the Hauptmumienbank Member of the Vellerat Formation (see Figure 1 for geographical position of sections): (a) Voyeboeuf section from SB Ox6+ to MFS Ox6+; (b) Savagnières section from SB Ox6+ to MFS Ox6+; (c) Pertuis section from SB Ox6+ to MFS Ox6+; (d) Top part of the Vorbourg section around MFS Ox6+; (e) Base and middle part of the Vorbourg section above SB Ox6+. The numbers refer to the elementary sequences within the small-scale sequences. Compare with logs in Figures 10 and 11. 


\begin{tabular}{|c|c|c|c|c|}
\hline \multicolumn{5}{|c|}{ Skeletal facies } \\
\hline$M-W-P$ & $\begin{array}{l}\text { dominated by semi-restricted/normal-marine fauna (ostracodes, inocerams), foraminifera (Textulariids, Miliolids, } \\
\text { Lenticulina), quartz, organic matter debris }\end{array}$ & $\begin{array}{l}\text { low to } \\
\text { moderate }\end{array}$ & $\begin{array}{l}\text { protected lagoon with low diversity fauna } \\
\text { (probably tidal channels or bioclastic bars) }\end{array}$ & S1 \\
\hline$W-P$ & $\begin{array}{l}\text { dominated by normal-marine fauna (echinoderms, inocerams, oysters, serpulids, brachiopods), foraminifera } \\
\text { (Lenticulina, Textulariids, Miliolids), type } 2 \text { and } 3 \text { oncoids, litho-oncoids, peloids, quartz }\end{array}$ & moderate & semi-open lagoon & $\mathrm{s} 2$ \\
\hline W - P - G & $\begin{array}{l}\text { dominated by normal-marine fauna (brachiopods, oysters, echinoderms, calcareous sponges, clusters of serpulids, } \\
\text { corals, locally foraminifera (Textulariids, Miliolids), peloids }\end{array}$ & $\begin{array}{l}\text { moderate to } \\
\text { high }\end{array}$ & open lagoon (bioclastic bars) & s3 \\
\hline \multicolumn{5}{|c|}{ Oncoid-rich facies } \\
\hline$W-P$ & $\begin{array}{l}\text { type } 1 \text { oncoids, foraminifera (Textulariids, Lenticulina, Miliolids), quartz; normal-marine fauna (bivalves, } \\
\text { echinoderms, ostracodes, serpulids), peloids, organic matter, grapestones }\end{array}$ & $\begin{array}{l}\text { low to } \\
\text { moderate }\end{array}$ & semi-open lagoon with siliciclastic input & ON1 \\
\hline$W-P-R$ & $\begin{array}{l}\text { type } 2 \text { oncoids; normal-marine fauna (ostracodes, inocerams, oysters, serpulids, echinoderms), foraminifera } \\
\text { (Textulariids, Lenticulina, Miliolids), type } 3 \text { oncoids, peloids, quartz }\end{array}$ & $\begin{array}{l}\text { low to } \\
\text { moderate }\end{array}$ & semi-open lagoon with siliciclastic input & ON2 \\
\hline$W-P$ & type 2 oncoids, type 3 ooids; type 2 ooids, peloids, foraminifera (Textulariids), little quartz & $\begin{array}{l}\text { low to } \\
\text { moderate }\end{array}$ & semi-open lagoon & ON3 \\
\hline$W-P-R$ & $\begin{array}{l}\text { type } 3 \text { and } 2 \text { oncoids, type } 3 \text { ooids; foraminifera (Textulariids, Mohlerina, Miliolids), peloids, type } 2 \text { ooids, normal- } \\
\text { marine fauna (brachiopods, echinoderms) }\end{array}$ & $\begin{array}{l}\text { low to } \\
\text { moderate }\end{array}$ & open lagoon & ON4 \\
\hline W- F & $\begin{array}{l}\text { type } 3 \text { oncoids; normal-marine fauna (serpulids, oysters, brachiopods, echinoderms, inocerams), foraminifera } \\
\text { (Textulariids, Lenticulina, Mohlerina, Miliolids), peloids, type } 2 \text { oncoids }\end{array}$ & $\begin{array}{l}\text { low to } \\
\text { moderate }\end{array}$ & open lagoon & ON5 \\
\hline$M-W-F$ & $\begin{array}{l}\text { type } 3 \text { and } 4 \text { oncoids; foraminifera (Mohlerina, Textulariids, Miliolids), normal-marine fauna (echinoderms, oysters, } \\
\text { brachiopods, gastropods), type } 2 \text { oncoids, micritized type } 3 \text { ooids, peloids }\end{array}$ & $\begin{array}{l}\text { low to } \\
\text { moderate }\end{array}$ & open lagoon & ON6 \\
\hline \multicolumn{5}{|c|}{ Ooid-rich facies } \\
\hline G & micritized type 3 ooids; type 3 ooids, type 2 oncoids, litho-oncoids, grapestones & high & ooid bars & 001 \\
\hline$P-G$ & $\begin{array}{l}\text { type } 3 \text { ooids partly micritized; type } 2 \text { ooids, normal-marine fauna (echinoderms, coral rubble), peloids, type } \\
2 \text { oncoids, grapestones, lithoclasts }\end{array}$ & $\begin{array}{l}\text { moderate to } \\
\text { high }\end{array}$ & ooid bars - semi-open lagoon & 002 \\
\hline$W-P$ & $\begin{array}{l}\text { micritized type } 3 \text { ooids, foraminifera (Textulariids, Miliolids, Lenticulina); type } 2 \text { ooids, type } 2 \text { oncoids, normal- } \\
\text { marine fauna (brachiopods, serpulids), peloids, litho-oncoids }\end{array}$ & moderate & $\begin{array}{l}\text { oo-bioclastic bars - semi-open/open } \\
\text { lagoon }\end{array}$ & 003 \\
\hline$W-P-G$ & $\begin{array}{l}\text { type } 3 \text { ooids; type } 2 \text { oncoids, foraminifera (Textulariids, Lenticulina), normal-marine fauna (bryozoans, ostracodes, } \\
\text { bivalves) to open-marine fauna (brachiopods, echinoderms, serpulids, corals), peloids, quartz, grapestones }\end{array}$ & $\begin{array}{l}\text { moderate to } \\
\text { high }\end{array}$ & $\begin{array}{l}\text { oo/onco/peloid bars - semi-open/open } \\
\text { lagoon }\end{array}$ & 004 \\
\hline W - P - G & $\begin{array}{l}\text { type } 3 \text { ooids partly micritized, type } 2 \text { oncoids, normal-marine fauna (brachiopods, echinoderms, corals); } \\
\text { peloids, foraminifera (Textulariids, Lenticulina, Miliolids, Mohlerina), type } 2 \text { ooids }\end{array}$ & $\begin{array}{l}\text { moderate to } \\
\text { high }\end{array}$ & oo-onco-bioclastic bars - open lagoon & 005 \\
\hline \multicolumn{5}{|c|}{ Peloid-rich facies } \\
\hline$W-P$ & $\begin{array}{l}\text { peloids; normal-marine fauna (echinoderms, inocerams, ostracodes, oysters, brachiopods), foraminifera } \\
\text { (Textulariids, Lenticulina, Milliolids), locally quartz, organic matter debris }\end{array}$ & moderate & $\begin{array}{l}\text { protected/semi-open lagoon (tidal } \\
\text { channel?) }\end{array}$ & P1 \\
\hline$M-W-P$ & $\begin{array}{l}\text { peloids, foraminifera (Textulariids, Lenticulina), normal-marine fauna (dasycladaceans, ostracodes, } \\
\text { bryozoans, bivalves, serpulids, echinoderms, corals, brachiopods, oysters), quartz; type } 2 \text { and } 1 \text { oncoids }\end{array}$ & moderate & semi-open lagoon (tidal channel?) & $\mathrm{P} 2$ \\
\hline$P$ & $\begin{array}{l}\text { peloids, micritized type } 3 \text { ooids, type } 2 \text { oncoids, little quartz; foraminifera (Textulariids, Miliolids, Lenticulina), } \\
\text { corals, brachiopods, echinoderms, bivalves, locally type } 3 \text { and } 2 \text { ooids }\end{array}$ & moderate & semi-open lagoon (tidal channel?) & P3 \\
\hline W & $\begin{array}{l}\text { peloids, foraminifera (Miliolids, Textulariids, Mohlerina, Lenticulina), normal-marine fauna (echinoderms, } \\
\text { brachiopods); type } 3 \text { oncoids }\end{array}$ & moderate & open lagoon & P4 \\
\hline \multicolumn{5}{|c|}{ Coral facies } \\
\hline $\begin{array}{c}\mathrm{B} \\
(\mathrm{M}-\mathrm{W}-\mathrm{P})\end{array}$ & $\begin{array}{l}\text { microencrusted corals in situ and rubble; peloids, type } 3 \text { and } 1 \text { ooids, type } 2 \text { oncoids, normal-marine fauna } \\
\text { (brachiopods, serpulids, sponges), foraminifera (Placopsilina, Bullopora), lithoclasts, quartz }\end{array}$ & high & open lagoon & $\mathrm{C} 1$ \\
\hline$B(P)$ & $\begin{array}{l}\text { microencrusted corals in situ and/or rubble; normal-marine fauna (brachiopods, sponges, serpulids, } \\
\text { echinoderms, bivalves), peloids, type } 3 \text { ooids, type } 2 \text { oncoids }\end{array}$ & high & open lagoon & $\mathrm{C} 2$ \\
\hline \multicolumn{5}{|c|}{ Siliciclastics } \\
\hline$c-m$ & $\begin{array}{l}\text { unfossiliferous or with semi-restricted fauna (charophytes, gastropods, ostracodes), foraminifera, serpulids, coal } \\
\text { debris }\end{array}$ & moderate & protected lagoon & M1 \\
\hline$m-c$ & semi-restricted and normal-marine fauna (echinoderms, bivalves, foraminifera), oncoids, serpulids, ostracodes & moderate & protected to semi-open lagoon & M2 \\
\hline$m-c$ & normal-marine fauna (brachiopods, echinoderms), corals, ooids & moderate & open lagoon & M3 \\
\hline
\end{tabular}

Fig. 5. Classification of facies and microfacies in the studied sections based on observations from field, rock slabs, and thin sections. Oncoid types from Védrine et al. (2007) and Védrine (2007). Ooid types based on Strasser (1986). For symbols describing texture see Figure 9.

composed of oncoids, peloids, ooids, and/or various bioclasts (bivalves, echinoderms, benthic foraminifers, serpulids, ostracodes, brachiopods, corals). These deposits are representative of lagoonal environments with more or less normal-marine conditions (Figs. 5 and 6). Marls contain various bioclasts (charophytes, gastropods, ostracodes, serpulids, bivalves, benthic foraminifers, echinoderms, corals, brachiopods), characteristic of semi-restricted to normal-marine conditions, non-skeletal particles (oncoids and ooids), and non-calcareous elements (quartz and coal debris). In the studied sections, siliciclastics are generally more abundant in proximal environments (protected lagoon to semi-open lagoon) but could also be transported by currents onto the platform and deposited in depressions (Pittet 1996). For example, the basal marly deposits of the HautesRoches section, containing abundant charophyte stems and gyrogonites, indicate freshwater conditions in a coastal pond while the marly deposits in the top part of the Vorbourg section, containing abundant brachiopods, benthic foraminifers, and oncoids, point to normal-marine conditions in an open lagoon.

Some carbonate components are relevant proxies for palaeoenvironmental interpretations. For example, the oncoids found in the Hauptmumienbank Member display a wide variability in size, shape, surface morphology, and composition. Four types of lagoonal oncoids are distinguished and related 
to particular environmental conditions (Védrine et al. 2007; Védrine 2007; Figs. 5 and 7). Type 1 oncoids have micritic laminations rather difficult to distinguish, characterizing protected lagoons with moderate- to low-energy conditions. Type 2 oncoids present micritic laminations with a low-diversity fauna in the cortex. They are related to environments with high and/or intermittent energy conditions in semi-open lagoons. Type 3 oncoids are composed of an alternation of organism-bearing laminations and thin micritic laminations. The organism-bearing laminations are formed by Bacinella irregularis (Radoicic 1959) and Lithocodium aggregatum (Elliott 1956). This oncoid type is characteristic of low-energy environments in open lagoons but with periodic agitation. Type 4 oncoids display irregular morphologies and are composed of a Bacinella-Lithocodium meshwork. These oncoids formed in very low-energy settings allowing for microbial growth. In some cases, lithoclasts display an oncoid cortex (litho-oncoids).

In the examined shallow platform deposits, three types of ooids are observed (Figs. 5 and 7). Ooids with laminated radial cortices (type 3 of Strasser 1986) are very common and imply lagoonal environments (shallow subtidal) with alternating high and low water energy. These radial ooids commonly display a partial or complete micritization ("micritized ooids"). Some oo-oncoids (type 2 of Strasser 1986) are occasionally found in the studied deposits. They consist of a radial ooid, which is enveloped by an oncoid cortex characterized by irregular thin micritic laminae. These ooids are characteristic of quiet waters in lagoonal environments (shallow subtidal) where microbial activity was favoured.

\section{Microfacies classification}

Six types of facies are distinguished in the studied sedimentary rocks (Fig. 5). Skeletal facies are subdivided into 3 microfacies types (S1 to S3; Figs. 5 and 7a-b). Wackestones and packstones with semi-restricted and normal-marine fauna are attributed to protected and semi-open to open lagoonal environments (Fig. 6). Oncoid-rich facies present 6 microfacies types (ON1 to ON6; Figs. 5 and $7 \mathrm{c}-\mathrm{d}$ ). The discriminating criteria are the oncoid type and the associated fauna. Type 1 and 2 oncoids are dominant in low- and moderate-energy settings (wackestones and packstones) in semi-open lagoons. Type 3 and 4 oncoids characterize low- to moderate-energy settings in open lagoons. Oncoid-rich rudstones occur locally and suggest higher energy and possibly the formation of oncoid bars. Ooid-rich facies are subdivided into 5 microfacies types (OO1 to OO5; Figs. 5 and $7 \mathrm{e}-\mathrm{f})$. Ooids are found in wackestones to grainstones and are commonly mixed with type 2 oncoids, peloids, and bioclasts. Ooid-dominated bars (radial and micritic ooids) and mixed bars are recognized. Ooid-dominated bars are characterized by a grainstone-packstone texture and considered as the active part of bars in the intertidal to shallow subtidal zones (OO1 and $\mathrm{OO} 2$ ). Mixed bars have a wackestone to locally grainstone texture with ooids, bioclasts, peloids, and oncoids; they probably correspond to the inactive part and/or the periphery of bars in the subtidal zone. Peloidal facies are subdivided into 4 microfacies types (P1 to P4; Figs. 5 and 7g-h). Peloid-rich facies have a mudstone to packstone texture with a low- to high-diversity fauna and are present from protected lagoon to open lagoon. Coral facies are subdivided into 2 microfacies types (C1 and C2; Fig. 5). The subdivision is based on the texture and the constituents in the sediment surrounding the corals. In the present study, in-situ corals have been encountered only in the Hautes-Roches and Court sections (for a detailed description of the Oxfordian coral-reef microfacies in the Swiss Jura see Dupraz 1999 and Dupraz \& Strasser 1999).

Siliciclastic deposits are subdivided into 3 microfacies types (M1 to M3; Fig. 5) depending on the fossil assemblage: restricted/semi-restricted fauna (charophytes, gastropods, ostracodes, coal debris) and normal-marine fauna (bivalves, echinoderms, benthic foraminifers, brachiopods, corals). Transported ooids and type 2 oncoids are also found in some marls. These fa-

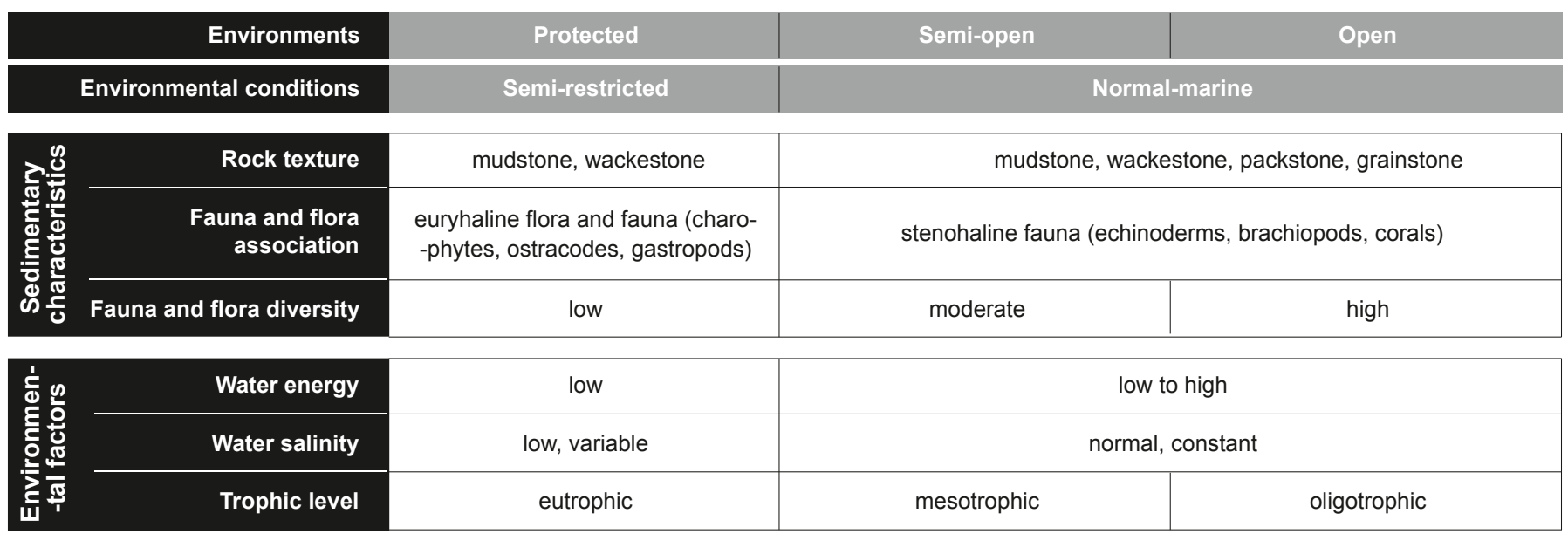

Fig. 6. Environments and environmental conditions interpreted from fauna and floral associations and biodiversity, and inferred energy, salinity, and trophic levels. 

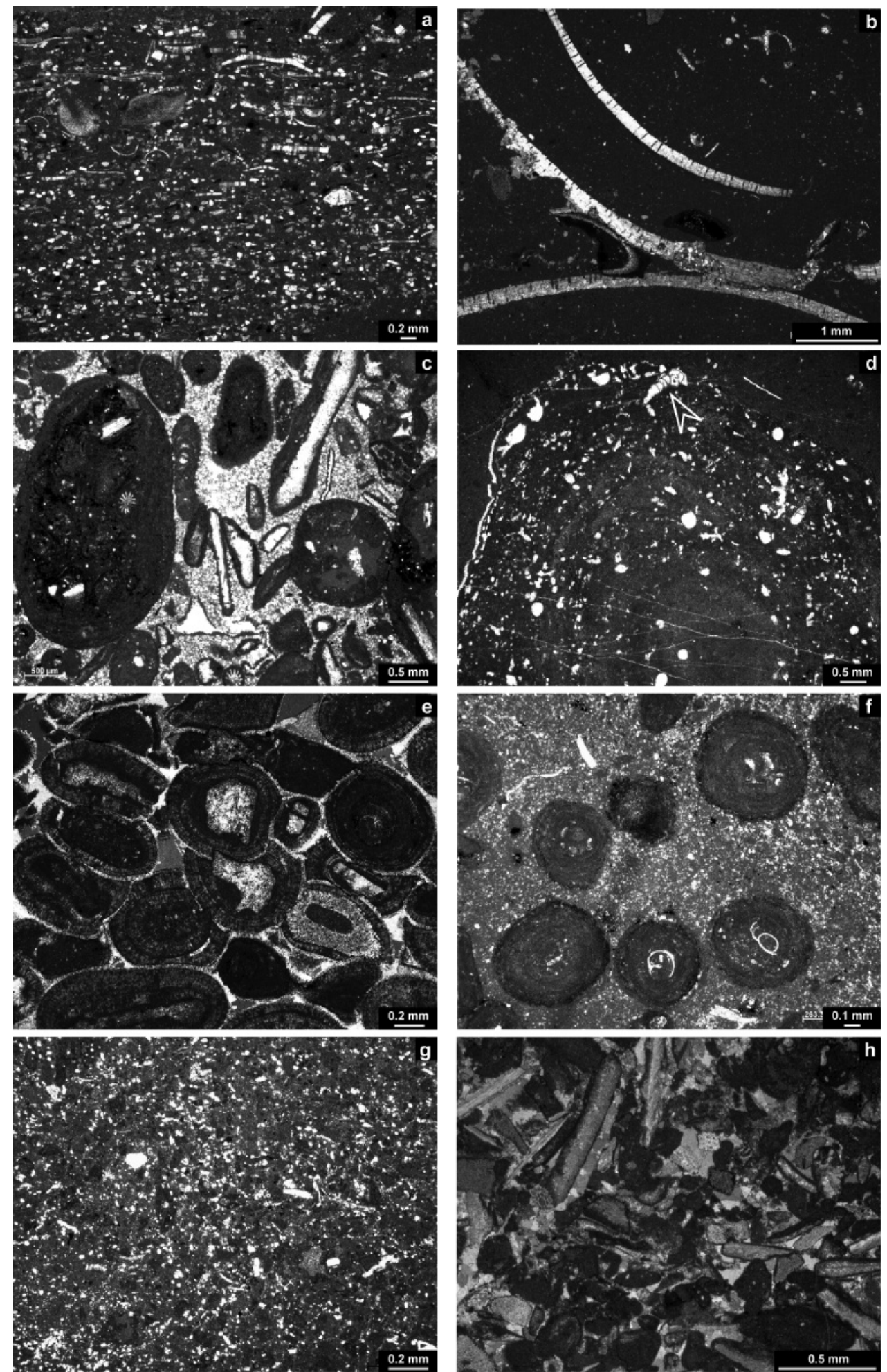

Fig. 7. Microfacies examples from the Hauptmumienbank and Steinebach members: (a) Peloidal and bioclastic packstone rich in quartz. Microfacies S1, Savagnières section, Sa-1A; (b) Wackestone rich in Terebratulid brachiopods. Microfacies S3, Vorbourg section, Vo-N; (c) Type 2 oncoid packstone with a dolomitized matrix. Microfacies ON2, Vorbourg section, Vo-12; (d) Type 3 oncoid with a cortex composed of irregular Bacinella-Lithocodium laminations and thinner micritic laminations. The contour is lobate. Note Troglotella incrustans perforating the cortex (arrow). Microfacies ON4, Pertuis section, Pe-81A; (e) Type 3 ooid grainstone with isopachous cement around grains. Note compaction that post-dates the first phase of cementation. Microfacies OO2, Hautes-Roches section, Hr-25; (f) Wackestone with micritized ooids in a partially dolomitized matrix. Microfacies OO3, Vorbourg section, Vo-32; (g) Peloidal packstone. Microfacies P1, Pertuis section, Pe-F; (h) Bioclastic and peloidal packstone. Microfacies P2, Vorbourg section, Vo-10C. 
cies characterize depositional environments from the protected to the open lagoon.

\section{Depositional model}

Based on facies and microfacies analysis, a depositional model is proposed for the studied deposits. It consists of a shallow carbonate platform with tidal flats, oncolitic lagoons, oolitic bars, and coral reefs (Fig. 8). Tidal flats border shallow lagoons (this is inferred: tidal flat facies has been seen only in a thin interval in the Court section). Lagoons are located behind barriers, which may be reefs or carbonate sand shoals. Inlets cut through the barriers and permit tidal currents to transport sediment and water into and out of the lagoon. Three types of shallow lagoon are considered in this study. Protected lagoons consist of marls and limestones with a semi-restricted fauna (e.g., bivalves, gastropods, ostracodes, inocerams, serpulids, Miliolids), a relatively low-diversity fauna, and an intense bioturbation (Fig. 6). The semi-open and open lagoons are mainly characterized by carbonate-dominated facies, from mudstone to grainstone, with a higher biodiversity implying normal salinity and a relatively low turbidity (Fig. 6). Coral patch-reefs and/or coral carpets commonly occur in semi-open to open lagoons. Coral reefs and ooid bars exist on the platform edge or within the platform, probably depending on tectonically induced morphology. Siliciclastics are common but heterogeneously distributed. They concentrate in depressions formed by differential subsidence, or in-between ooid shoals and coral reefs (Pittet 1996; Hug 2003).

\section{Sequence analysis}

Two orders of depositional sequences are identified in the studied interval: small-scale and elementary sequences. Elementary sequences are the smallest units recognizable in the field. They are defined by a vertical facies evolution (deepening then shallowing trends) that translates one cycle of environmental change, reflecting sea-level change (Strasser et al. 1999). Some elementary sequences are aggrading and do not show any facies change. Nevertheless, their boundaries indicate breaks in sedimentation. The thicknesses of elementary sequences range from a few centimetres to a few tens of centimetres. In the studied sections, an elementary sequence is in many cases composed of three limestone beds delimited by marl layers. When facies contrasts are not well developed or when autocyclic processes predominated (i.e. in oolitic facies), it is not possible to clearly identify elementary sequences. Small-scale sequences measure from one to several meters and are generally composed of five elementary sequences. Differences in thickness and large variations of facies between sections are common. The studied interval is too short to define the medium-scale sequence Ox6+: its interpretation is taken from Hug (2003) and Strasser

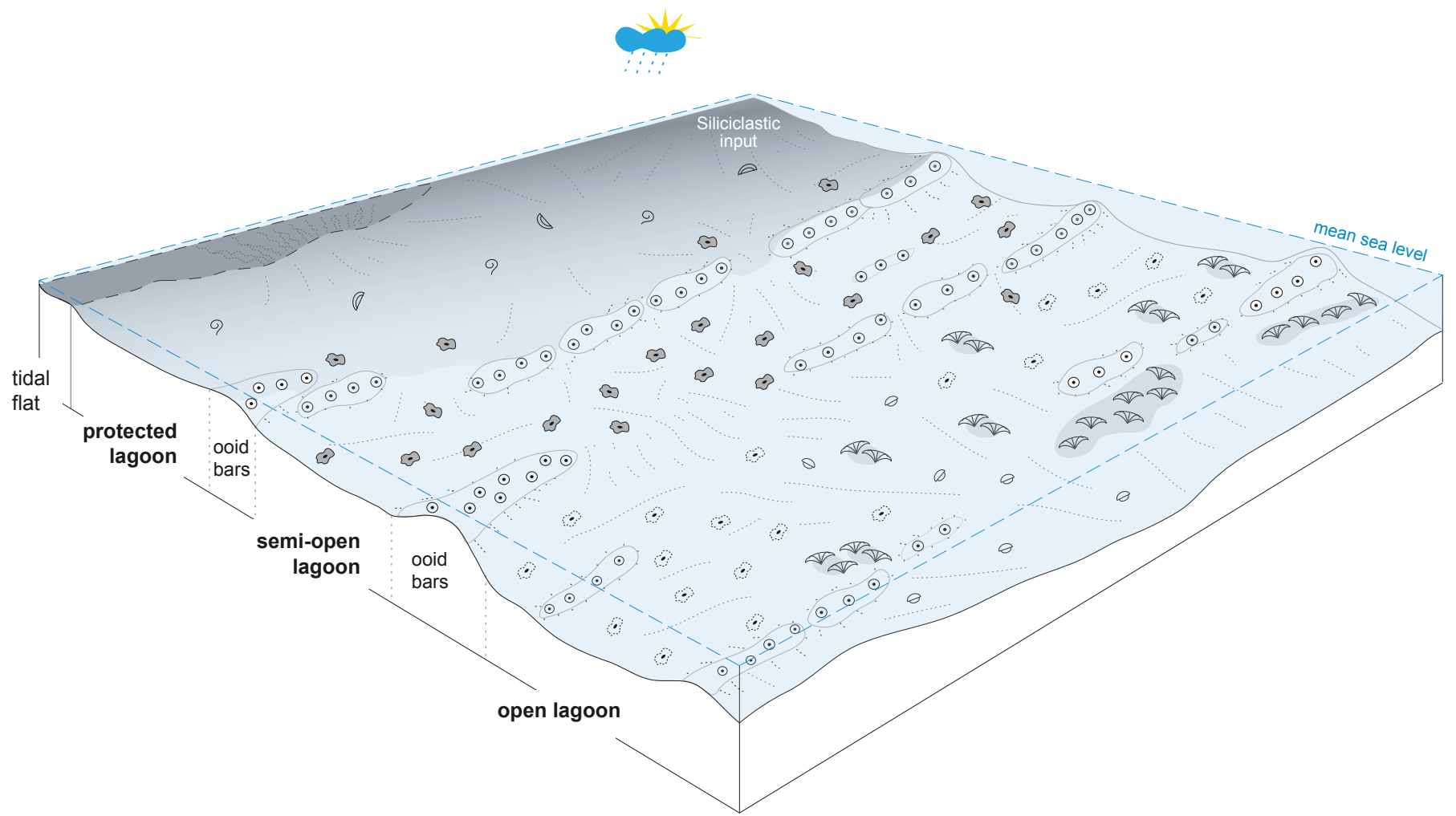

Fig. 8. Schematic depositional model of the platform during deposition of the Hauptmumienbank and Steinebach members. The siliciclastic influx comes from the north. Refer to text for discussion. Symbols are as in Figure 9. 
(2007) who analysed longer sections. Sequence boundaries especially of small- and medium-scale sequences are not always defined by a clearly marked surface but rather by an interval of relatively shallowest facies. In such cases, the term sequenceboundary zone is used (Strasser et al. 1999). The same holds for the maximum flooding, which may be indicated rather by the relatively deepest or most open-marine facies than by a surface such as a hardground.

\section{The Vorbourg section}

In order to reconstruct the evolution of the depositional environments through time, all sections have been analysed and interpreted in great detail (Védrine 2007). In this paper, however, only the Vorbourg section is described as an example. This section is located in northwestern Switzerland north of Delémont (canton Jura; Fig. 1) and crops out in a parking lot along the small road that cuts through the Béridier anticline, close to the Vorbourg chapel. It is a good reference section for the Hauptmumienbank Member (cf. section RG 366 in Gygi 2000b). Along the parking area, marly deposits, which are partly covered by vegetation, constitute the Röschenz Member dated of the lower Hypselum subzone (Gygi 1995; Fig. 4e). The massive limestones of the Hauptmumienbank and Steinebach members, dated of the upper Hypselum subzone, are exposed in the southern extremity of the parking. The studied interval consists of $12.8 \mathrm{~m}$ lagoonal deposits, covering the top part of the marly Röschenz Member and most of the oncoid-rich Hauptmumienbank Member (Fig. 10; legend in Fig. 9).

\section{(1) Sedimentological interpretation}

The base of the section (from 0 to $0.9 \mathrm{~m}$; Fig. 10) consists of ooid-peloid-foraminifer packstones interpreted as higher-energy deposits and as having resulted from washovers, and of fossiliferous yellowish marls with a semi-restricted fauna association (ostracodes, gastropods, and type 2 oncoids), suggesting a more protected lagoonal environment.

Then the sedimentation style changes: marly deposits disappear and are replaced by massive and thick limestone beds rich in oncoids. The interval above this well-marked facies change (from 0.9 to $1.85 \mathrm{~m}$ ) consists of (a few tens of centimetres) thick packstone beds rich in type 2 oncoids, foraminifers, and radial ooids. These oncoid beds are interpreted as semi-open lagoonal deposits. The following bed (from 1.85 to $2.05 \mathrm{~m}$ ), dominated by brachiopods, echinoderms, and coral rubble, marks an important opening and deepening of the depositional environment. Radial ooid grainstone bars migrated over this bioclastic deposit and momentarily interrupted the oncolitic sedimentation (from 2.05 to $3.2 \mathrm{~m}$ ). Ooid bars then become thinner and (at $3.15 \mathrm{~m}$ ) pass into a thick bioturbated wackestone bed with micritized ooids, Bacinella-Lithocodium (type 3) oncoids, foraminifers, and brachiopods. This evolution suggests lower-energy conditions in a deeper, open lagoon. This massive bed is followed by a thinner bed (from 3.8 to $4 \mathrm{~m}$ ) cut by erosional surfaces and interpreted as a channel deposit, which probably indicates a shallowing of the depositional environment. The following massive and thick bed (from 4 to $4.85 \mathrm{~m}$ ) consists of Bacinella-Lithocodium (type 3) oncoid wackestones-floatstones and is interpreted as an open lagoonal deposit. At its top,

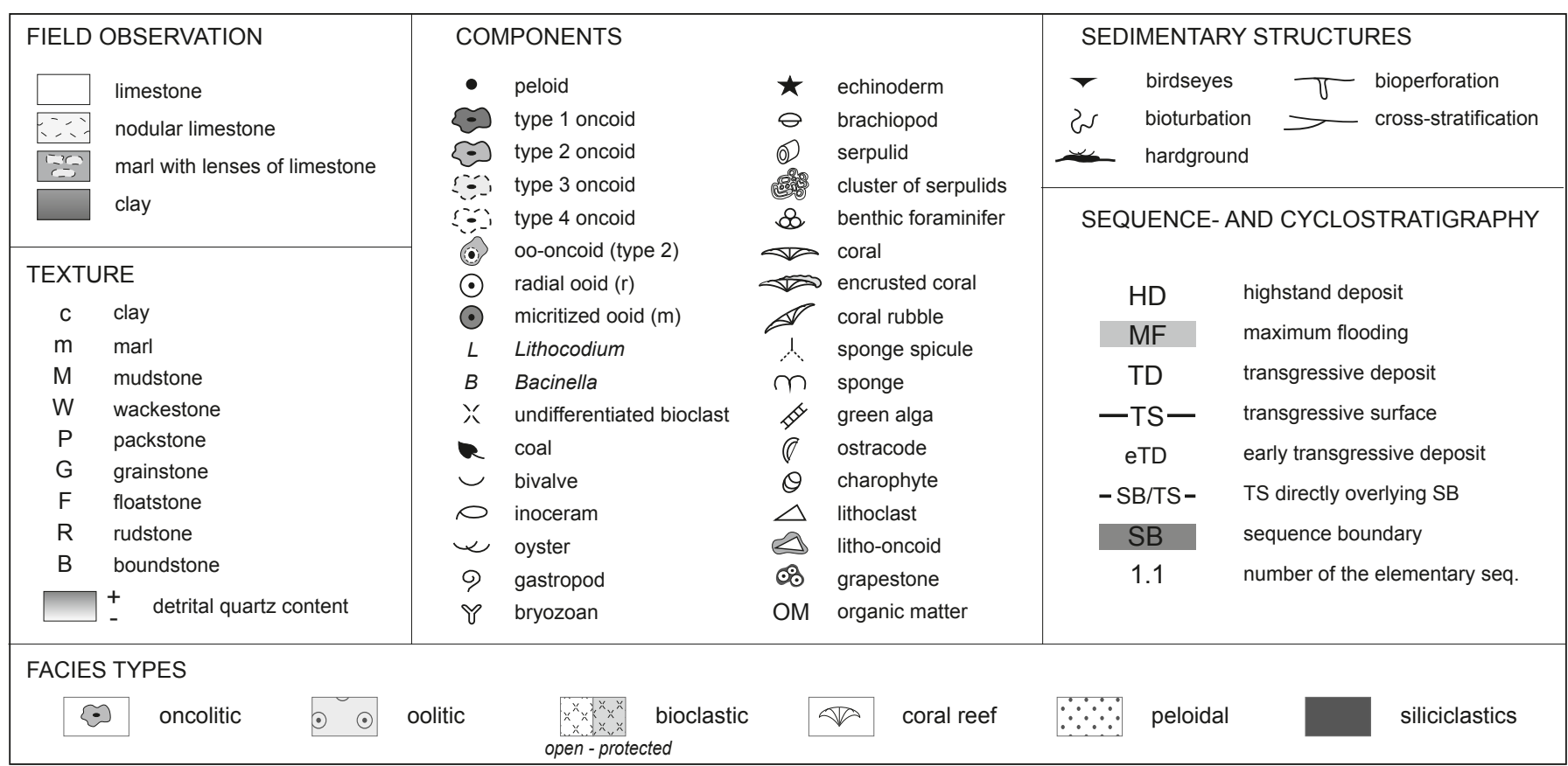

Fig. 9. Legend to sections and models.

256 S. Védrine \& A. Strasser 
a small channel occurs, pointing to a shallowing. The following thick bed (from 4.85 to $6.15 \mathrm{~m}$ ) is wackestone to packstone (locally rudstone) with Bacinella-Lithocodium (type 3) oncoids, foraminifers, and micritized ooids. This bed is followed by thin nodular rudstone beds (from 6.15 to $6.5 \mathrm{~m}$ ) rich in BacinellaLithocodium (type 3 ) oncoids and benthic foraminifers. These rudstones point to higher energy conditions probably due to a decrease of water depth. This interval is overlain (from 6.5 to $9.95 \mathrm{~m}$ ) by cross-bedded packstone bars containing micritized ooids. A nodular wackestone bed rich in micritized ooids (from $9.95 \mathrm{~m}$ ) and a wackestone bed rich in oo-oncoids, peloids, and foraminfera (from $10.25 \mathrm{~m}$ ) suggest lower energy conditions. At $10.7 \mathrm{~m}$, a perforated and oyster-encrusted hardground caps these beds and probably reflects a sediment starvation (lower accumulation rate) during a rapid deepening of the depositional environment. The hardground is covered by an important marl interval. This abrupt lithological change marks the turnover towards a siliciclastic-dominated sedimentary system. It was probably caused by a climatic change to more humid conditions in the hinterland and by a higher potential for sediment transport from the hinterland due to the maximum-flooding conditions, which both led to increased terrigenous input (Hug 2003). The marly level (from 10.7 to $11.9 \mathrm{~m}$ ) consists of yellowish marls rich in terebratulid brachiopods, benthic foraminifers, and type 2 oncoids. This interval includes three thin nodular limestone beds: one type 2 oncoid rudstone at $10.95 \mathrm{~m}$, one boundstone of serpulids with sponge spicules at $11.45 \mathrm{~m}$, and one wackestone rich in brachiopods and broken oncoids at $11.65 \mathrm{~m}$. In the final part of the section, limestone beds with brachiopods (from $11.9 \mathrm{~m}$ to top) dominate and represent open-marine conditions.

\section{(2) Sequence interpretation}

In the Vorbourg section, the marly interval at the top of the Röschenz Member exhibits lagoonal facies. However, in other sections, e.g. in the Hautes-Roches section, this level contains charophytes and coal debris. This interval is therefore interpreted as the medium-scale sequence boundary zone SB Ox6+ (Fig. 10). The following rapid lithological change (from marl to limestone), recognized all over the Swiss Jura, is interpreted as the major transgressive surface TS Ox6+, situated in the early Bimammatum zone (Fig. 3; see also Pittet 1996; Hug 2003).

Sequence boundaries, transgressive surfaces, and maximum floodings of elementary sequences are precisely defined from facies and microfacies analyses and stacking pattern. The sequence boundaries are in many cases directly overlain by well-marked transgressive surfaces. On the shallow platform, lowstand deposits are generally absent due to low accommodation during relative sea-level fall. However, early transgressive deposits (eTD) are interpreted when reworking is indicated above the sequence boundary but below the well-marked transgressive surface.

In small-scale sequence 1 , five elementary sequences have been identified. The first and second elementary sequences are rich in type 2 oncoids and interpreted as semi-open lagoonal deposits. In the first elementary sequence (1.1), the washover deposit at $0.85 \mathrm{~m}$ is interpreted as being part of the early transgression (eTD), the first nodular oncoid packstone bed is considered as the transgressive deposit, and the two following beds as the highstand deposit. The maximum flooding is placed at the slight texture change from packstone to wackestone/packstone (at $1.05 \mathrm{~m}$ ). The second elementary sequence is the thinnest one and shows a gradual decrease of quartz content. The peloid-foraminifer packstone (at $1.4 \mathrm{~m}$ ) is interpreted as an early transgressive deposit, and the two following beds as the transgressive and highstand deposits, respectively. The maximum flooding of this sequence is assumed to be located between the two massive beds (at $1.65 \mathrm{~m}$ ) where type 2 oncoids are abundant and brachiopods and corals are present. The third elementary sequence (1.3) is the thickest one of this section, suggesting maximum gain of accommodation. The bioclastic (i.e., brachiopods, echinoderms, corals) wackestone/packstone bed (from 1.85 to $2.05 \mathrm{~m}$ ) and the radial ooid grainstone beds (from 2.05 to $3.15 \mathrm{~m}$ ) are interpreted as transgressive deposits. High carbonate productivity and sediment accumulation kept up with or even outpaced the generally rising sea level (Colombié \& Strasser 2005). Thus, water depth stayed low and allowed for the formation of channels just below the maximum flooding. The facies evolution to bioturbated wackestone with micritized ooids and type 3 oncoids then points to more open-marine conditions in a deeper depositional environment. This facies change (at $3.15 \mathrm{~m}$ ) is interpreted as the maximum flooding of the third elementary sequence. This well-expressed change from high to low energy also corresponds to the maximum flooding of small-scale sequence 1 , which is confirmed by lateral correlation (see next chapter). The wackestone-floatstone beds (from 3.15 to $4 \mathrm{~m}$ ) rich in micritized ooids, BacinellaLithocodium oncoids, and foraminifers are interpreted as the highstand deposit in an open lagoon. Channels at the end of this highstand deposit probably indicate a slight decrease of accommodation and thus a relative sea-level fall. The fourth elementary sequence mainly consists of one massive and thick wackestone-floatstone bed rich in Bacinella-Lithocodium oncoids and foraminifers. A small channel occurs in the highstand deposit and suggests a slight sea-level fall. In the fifth elementary sequence, mainly composed of one massive and thick bed, a texture evolution from wackestone to packstone-rudstone suggests higher energy conditions in the second part of this bed, thus interpreted as the highstand deposit. There are no facies contrasts in elementary sequences 1.4 and 1.5 that allow placing the maximum flooding.

The rudstone interval (from 6.15 to $6.45 \mathrm{~m}$ ) suggests higher energy conditions and probably reflects a relative sea-level drop. This interval is thus interpreted as small-scale SB 2. Smallscale sequence 2 consists of five elementary sequences. The first one of these (2.1) begins with thin nodular oncoid rudstones, interpreted as early transgressive deposits (note that they are part of the sequence-boundary zone of small-scale sequence 2). The following oolitic packstones probably result from the lat- 

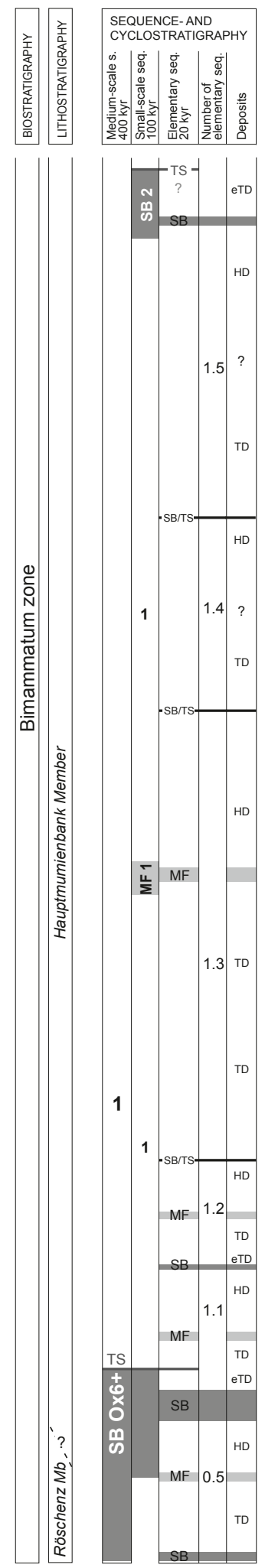

Vorbourg (1)
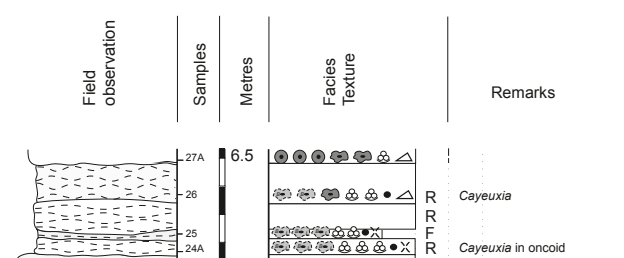

$\odot \odot \odot \oplus \oplus \triangle$

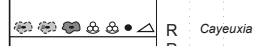

As
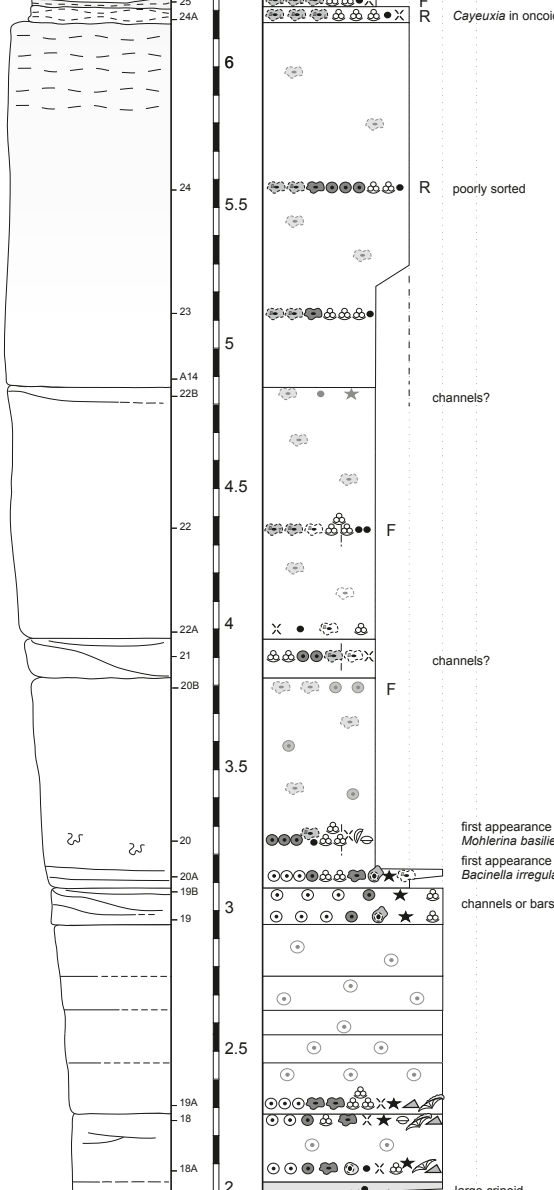

2.5

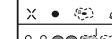

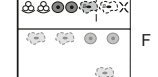

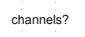

3.5

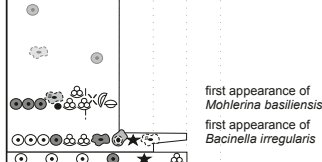

Bacinella irregularis

$\odot \odot$

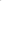

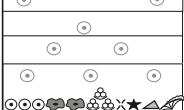

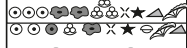

$\odot \odot \odot \odot \odot ・ \times \otimes^{\star}$

$\star \star \odot 0 \times \odot \circ \omega^{2}$ large crinoid

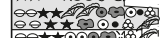

$\infty \infty$

1.5

$\odot \odot \infty$

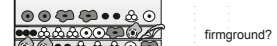

अ)

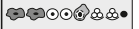

$\log 2000$

$\Leftrightarrow$

789

0 क्षश2

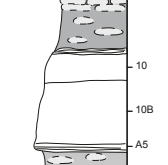

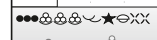

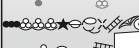

c $m$ M W P G

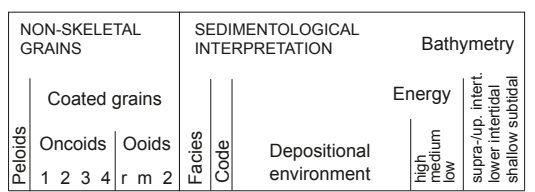

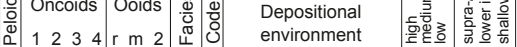

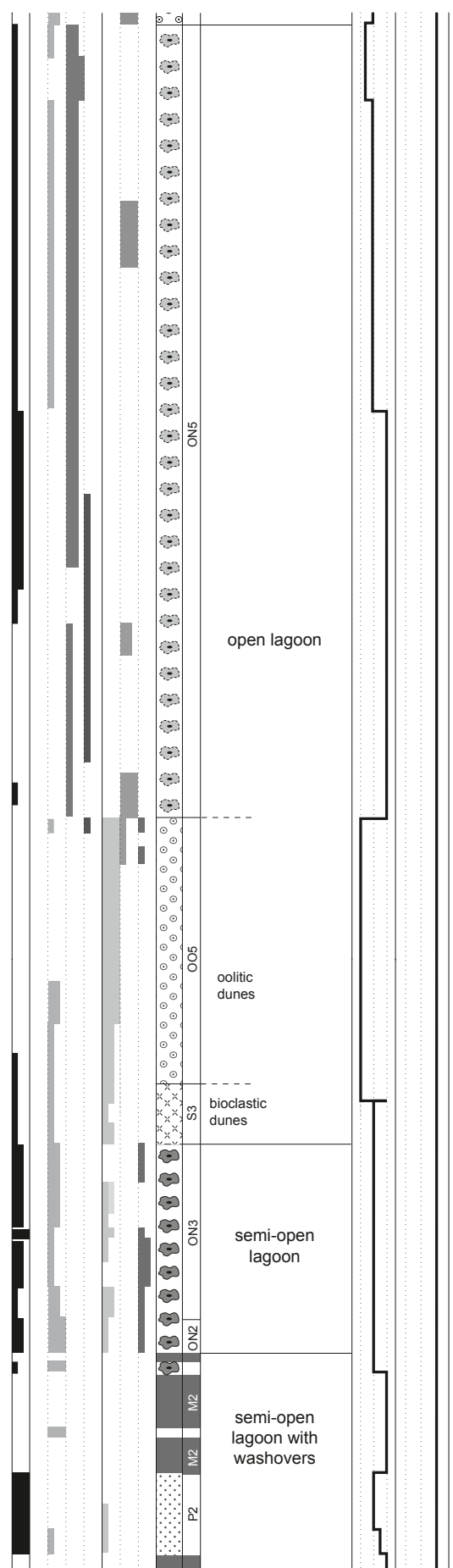

Fig. 10. Facies, microfacies analysis, palaeoenvironments, and sequence-stratigraphic interpretation of the Vorbourg section. The number of symbols translates the relative abundance of the component (0: absent, 1: present, 2: frequent, 3: dominant). For legend refer to Figure 9, for facies codes to Figure 5. For peloids, oncoids, and ooids, the relative abundance is indicated by the width of the bar. Components are indicated at sample positions; between samples, facies is observed on the outcrop, microfacies is inferred (grey symbols). 

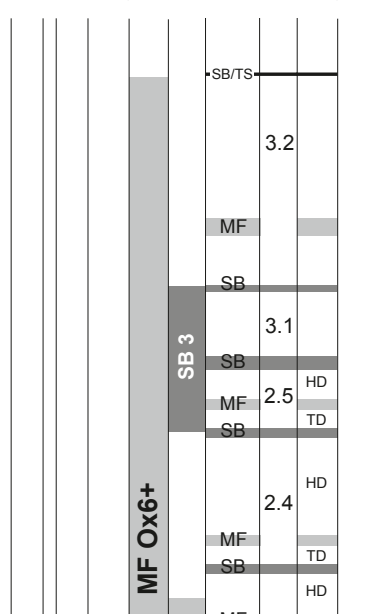

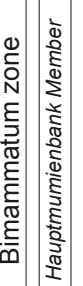
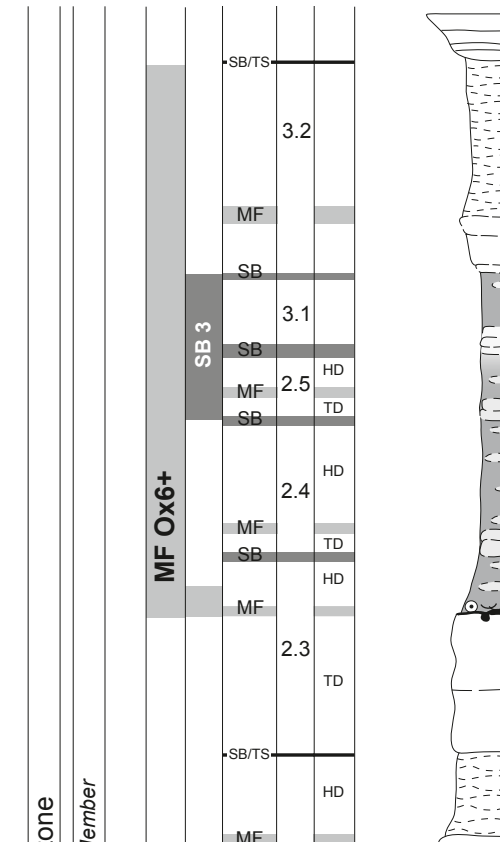

Vorbourg (2)

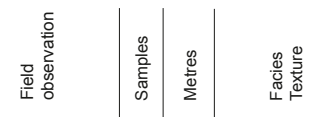

Remarks
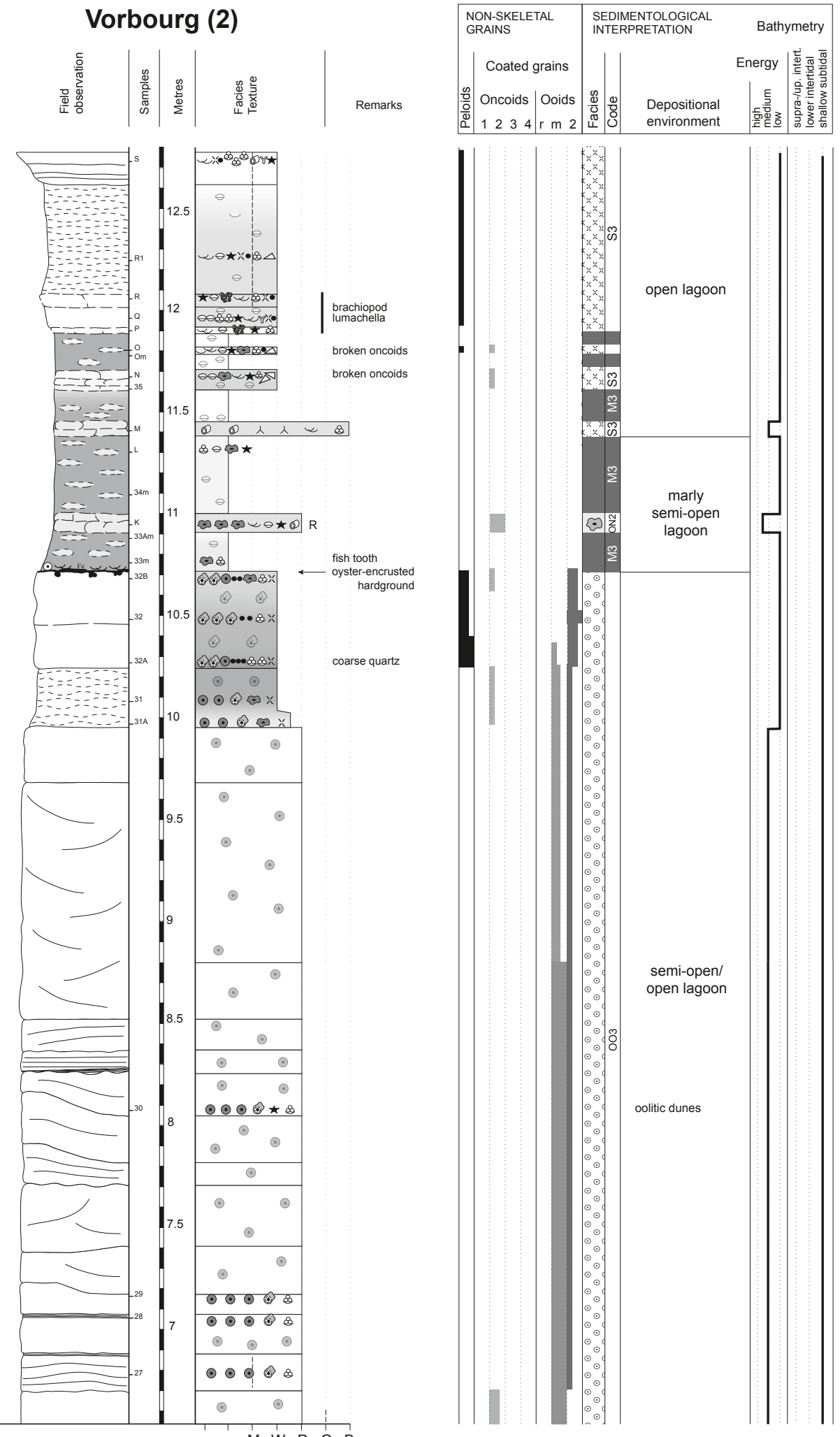

wos
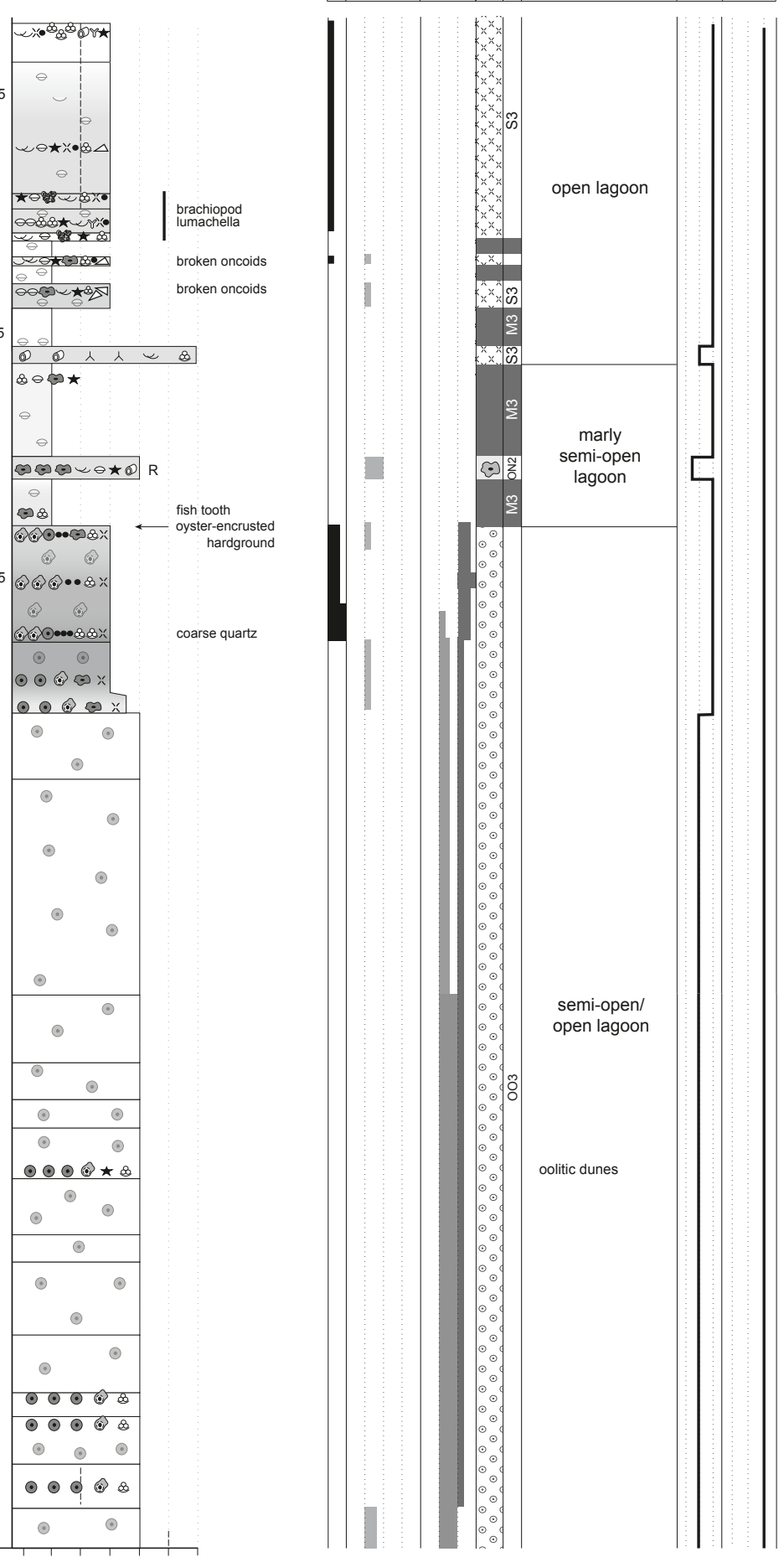

Fig. 10. (Continued). 


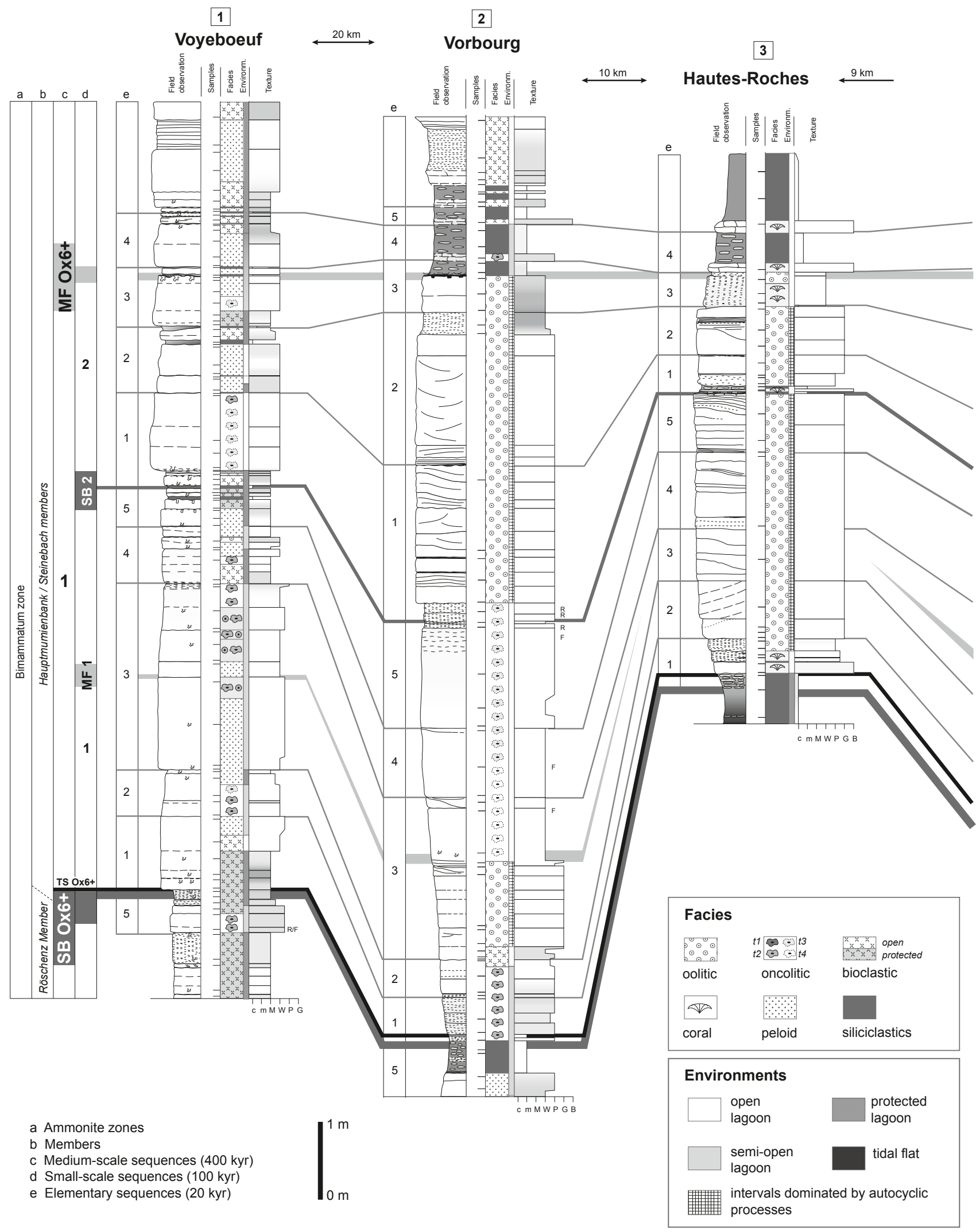

Fig. 11. High-resolution correlation of the small-scale (100 kyr) and elementary (20 kyr) sequences for the six studied sections in the Swiss Jura Mountains. See Figure 1 for the geographical position of sections. For discussion refer to text. Symbols are as in Figure 9. 


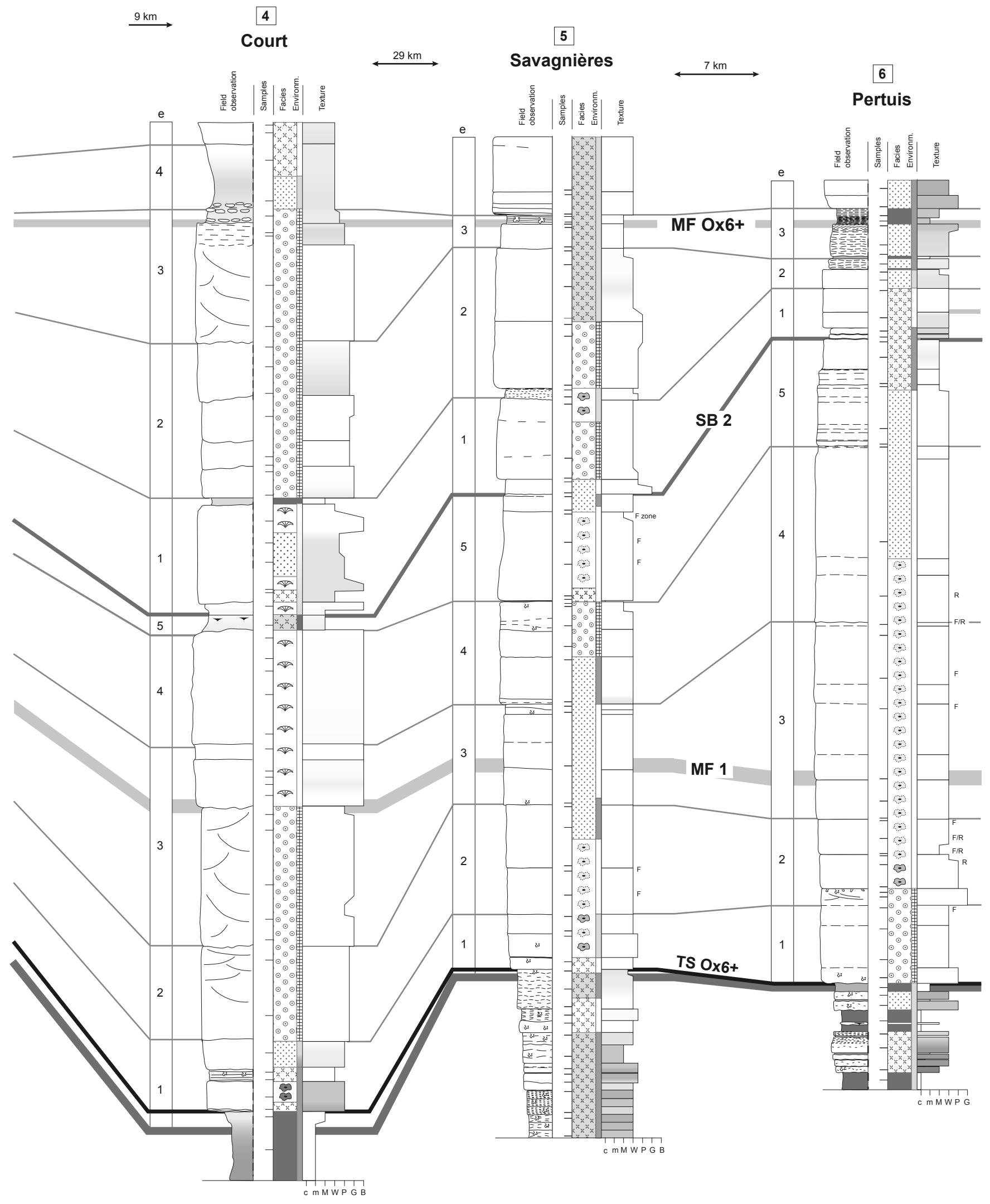

Fig. 11. (Continued). 
eral migration of ooid shoals, which makes the identification of elementary sequences difficult. However, fine laminations and thinner beds at $8.25 \mathrm{~m}$ suggest a hydrodynamic change, which is interpreted as corresponding to the sequence boundary of the second elementary sequence. The maximum flooding of sequence 2.2 is implied by the change from ooid packstones to nodular wackestones (at $9.95 \mathrm{~m}$ ), and the following sequence boundary is placed at the transition from nodular to more massive oolitic beds rich in coarse quartz (at $10.25 \mathrm{~m}$ ). The oyster-encrusted hardground (at $10.7 \mathrm{~m}$ ), which caps the top of the carbonate-dominated part of the Vorbourg section, is interpreted as the maximum-flooding surface of the third elementary sequence. This maximum-flooding surface also represents the maximum flooding of small-scale sequence 2 and corresponds to the medium-scale MF Ox6+.

The fourth and fifth elementary sequences are defined within the marly interval. Each is composed of a thin nodular limestone bed, interpreted as the transgressive deposit, and marls rich in brachiopods, interpreted as the highstand deposit. The serpulid boundstone (at $11.45 \mathrm{~m}$ ) suggests reduced salinity, the broken oncoids above imply reworking of sediment, and the thin elementary sequences 2.5 and 3.1 indicate low accommodation. These arguments allow placing small-scale sequence boundary zone SB 3.

\section{High-resolution correlation of the depositional sequences}

In order to monitor the evolution of the marine transgression following sequence boundary Ox6+ and the concomitant facies changes, the six studied sections, distant of a few kilometres to tens of kilometres, have been correlated at the level of elementary and small-scale sequences (Figs. 1 and 11). Based on the dominant facies and on their palaeogeographical positions, the sections are positioned from "proximal" (Voyeboeuf section, rather in the platform interior) to "distal" (Savagnières and Pertuis sections, closer to the open ocean). However, because platform morphology changed through time, these attributions can only indicate the general trend. Note that the vertical position of sections is adjusted to the medium-scale maximum flooding (MF Ox6+), considered as the most isochronous timeline. In some cases, especially around sequence-boundary zones of small- and medium-scale sequences, the exact positioning of elementary sequence boundaries or maximum floodings in a given section may be ambiguous. Here, a best-fit solution is proposed, which is based on the lateral correlation between all studied sections.

The high-resolution correlation shows that sequence boundaries and maximum floodings of the small-scale sequences have a good lateral continuity (Fig. 11). This suggests that the formation of the small-scale sequences was controlled by an external, allocyclic mechanism. Elementary sequences are sometimes more difficult to define and correlate. Nevertheless, most studied small-scale sequences include the same number of elementary sequences (i.e. five), suggesting a control on their sedimentation by a common external factor. Some intervals consist of cross-bedded oolites, particularly in the Hautes-Roches section (Fig. 11), where bedding surfaces may have formed as a result of autocyclic processes such as lateral migration of shoals. However, the lateral correlation with sections that contain contemporaneous low-energy deposits helps in proposing sequence boundaries even in such autocyclically controlled intervals. Based on previous studies (Pittet 1996, Hug 2003, Védrine 2007), the small-scale and the elementary sequences are interpreted as having formed through sea-level changes in tune with the orbital cycles of 100 and $20 \mathrm{kyr}$, respectively. Consequently, the sequence boundaries and maximum floodings drawn in Figure 11 can be considered as time lines (at least within a window of a few thousand years).

Thickness variations of small-scale and elementary sequences between sections reveal variable sediment accumulation rates. This is interpreted as resulting mainly from differential subsidence due to the activity of tectonic blocks (Allenbach 2002). The relief created by tectonics certainly contributed also to the general facies distribution. For example, the irregular distribution of siliciclastics can be explained by localized depressions that served as conduits (Pittet 1996; Hug 2003). Preferential growth of reefs and the initiation of ooid shoals on tectonic highs further enhanced the relief.

When comparing the facies of time-equivalent small-scale and elementary sequences between the Swiss Jura sections, significant lateral facies changes appear (Védrine 2007; Strasser \& Védrine 2009). These are illustrated for selected time intervals in Figure 12. At Vorbourg, Hautes-Roches, Court, and Pertuis, the top of the Röschenz Member consists of marly deposits, characterizing protected lagoonal sedimentation (Fig. 12a). At Hautes-Roches, also charophytes occur, pointing to freshwater influence. In the Voyeboeuf and Savagnières sections, the shallowest facies are made of bioclastic (mainly ostracodes and inocerams) mudstones-wackestones. These two facies types mark the medium-scale SB Ox6+ (Fig. 12a). Then, a rapid facies change, easily recognizable in most of the Swiss Jura deposits, occurs from marly deposits to massive limestone beds (Figs. 10, 11, and 12a). These limestones correspond to higher-energy facies and/or to more open-marine faunal assemblages, which overlie the transgressive surface TS Ox6+ (Fig. 12a). Elementary sequence 1.3 is the thickest elementary sequence of the first small-scale sequence (Fig. 12b), suggesting maximum accommodation gain. The maximum flooding of this elementary sequence coincides with the maximum flooding of small-scale sequence 1. At the end of the first small-scale sequence, a shallowing and possibly also a climate change to more humid conditions are indicated by a minor siliciclastic input marked by relatively thin clay layers (Voyeboeuf, Hautes-Roches, and Pertuis sections), by oncoid-rich rudstones (Vorbourg section), by bioclastic mudstones with birdseyes (Court section), and by a serpulid-rich layer (Savagnières section; Fig. 12c). This interval with thin beds and more or less rich in clays is interpreted as the small-scale SB 2. At the top of the carbonate-dominated part of the sections, a wavy to planar surface is observed, which is overlain by more or less

262 S. Védrine \& A. Strasser 
siliciclastics (Fig. 12d). In the "proximal" sections (Voyeboeuf, Vorbourg, Hautes-Roches, and Court) this wavy surface consists of a hardground, indicating sediment starvation. In the most "distal" sections (Savagnières and Pertuis), it consists of a relatively flat surface. This level belongs to the medium-scale MF Ox6+. The overlying siliciclastics, more abundant in the "proximal" part of the platform, possibly indicate more humid conditions in the hinterland. However, the effects of the transgression are not to exclude. Clays may thus have been remobilized, transported by currents throughout the platform, and deposited preferentially in depressions (Pittet 1996; Strasser et al. 1999; Védrine 2007).

The high-resolution correlation of sections at the scale of elementary sequences reveals a complex facies distribution and demonstrates the existence of a pronounced facies mosaic on the Swiss Jura platform. It also reflects the dynamics and the complexity of sedimentary systems where juxtaposed subenvironments evolved and shifted through space and time (Samankassou et al. 2003; Wright \& Burgess 2005; Védrine 2007; Strasser \& Védrine 2009).

\section{Platform evolution through time}

Assuming that the observed depositional sequences formed through superimposed frequencies of sea-level fluctuations controlled by orbital cycles, a precise time frame with a resolution of $20 \mathrm{kyr}$ can be constructed, within which the facies distribution will be discussed. Dominant facies and depositional environments within each elementary sequence are represented in a time-space diagram (Fig. 13a, b).

Siliciclastics (clays and quartz) occur abundantly at the base (sequence 0.5 and around the medium-scale SB Ox6+) of the Vorbourg, Hautes-Roches, and Court sections (Figs. 11 and 13a). They also occur around the medium-scale SB 2, especially in the Voyeboeuf and Hautes-Roches sections. Finally, siliciclastics are abundant around the medium-scale maximum flooding MF Ox6+, particularly in the Vorbourg and Hautes-Roches sections. Generally, siliciclastics are flushed onto the platform when increased rainfall in the hinterland activates river input, and/or by sea-level drop that forces the progradation of river deltas. The source area of the siliciclastics was located in the London-Brabant and/or Bohemian massifs, $400 \mathrm{~km}$ to the north (Fig. 2). Between the emerged lands and the studied shallow carbonate platform, a fluvial plain with an important potential of siliciclastic capture and storage probably existed. However, the climatic conditions on the platform were not necessarily the same as in the hinterland (Pittet 1996; Dupraz 1999; Hug 2003). For example, siliciclastics could have been mobilized when it rained in the hinterland and flushed onto the platform that was situated in a semi-arid climate belt. The abundance of siliciclastics around sequence boundaries SB Ox6+ and SB 2 probably results from the increase of terrigenous input due to relative sea-level fall. The presence of siliciclastics around the medium-scale maximum flooding MF Ox6+, however, is probably related to a climate change to more humid conditions in the hinterland and to a higher potential of sediment transport due to the maximum-flooding conditions.

Oncoid growth is mainly controlled by water energy, trophic level, and sediment accumulation rate (Védrine et al. 2007). Oncoid-rich facies appear more abundantly in the first small-scale sequence than in the second one. The Vorbourg and Pertuis sections are essentially composed of oncolitic facies in the first small-scale sequence, whereas in the Voyeboeuf, Court, and Savagnières sections oncolitic facies are patchily distributed and even inexistent in the Hautes-Roches section.

The various origins of peloids (e.g., bacterial, faecal, reworked cohesive mud, internal molds of fossils, complete micritization of grains; Flügel 2004) may explain the relatively widespread distribution of the peloid-rich facies in almost all sections.

Bioclastic facies result from the accumulation of debris of organisms. The fauna and flora association reflects the environmental conditions during their life under the condition that they have been deposited in situ. However, taphonomic processes such as time averaging through bioturbation and transport through currents cannot be excluded. Bioclastic facies with semi-restricted fauna, characteristic of protected lagoonal environments, are mainly present at the base (sequences 0.5 and 1.1) of the Voyeboeuf and Savagnières sections, and around SB 2 at Voyeboeuf, Court, and Savagnières. They also exist at the top of the Savagnières section around MF Ox6+. Bioclastic facies with normal-marine fauna, representing open-lagoonal environments, are less abundant and occur only patchily.

Coral facies, mainly composed of coral boundstones, reflect open-marine environments (i.e., semi-open and open lagoon in this study). Coral facies occur in the Court and Hautes-Roches sections. The first coral reefs appear in the Hautes-Roches section in sequence 1.1 and in the Court section in sequences 1.3 and 1.4. In the second small-scale sequence, coral facies are less abundant and correspond to small patch-reefs.

Ooids are formed and transported by tidal currents in shallow waters. Oolitic facies predominate in the Hautes-Roches, Court, and Vorbourg sections. The spatial and temporal distribution is patchy. In the first small-scale sequence, the Pertuis section reveals the first and single oolitic deposit while in the Hautes-Roches and Court sections, ooid accumulation starts somewhat later but then dominates especially at HautesRoches. The second small-scale sequence exhibits ooid deposits mainly in the Vorbourg, Hautes-Roches, and Court sections, and to a lesser extent in the Savagnières section. Oolitic deposits are mainly driven by autocyclic processes (e.g., progradation or lateral migration of sedimentary bodies), which can simulate depositional sequences or mask sequence boundaries and maximum-flooding surfaces (Strasser 1991). However, hydrodynamic changes denoted by sedimentary structures can point to relative sea-level fluctuations.

At the scale of the entire studied interval, the facies distribution on the Swiss Jura platform reveals a difference between the "proximal" and "distal" platform sections (Fig. 13a). Open lagoonal environments are more common in the "distal" plat- 


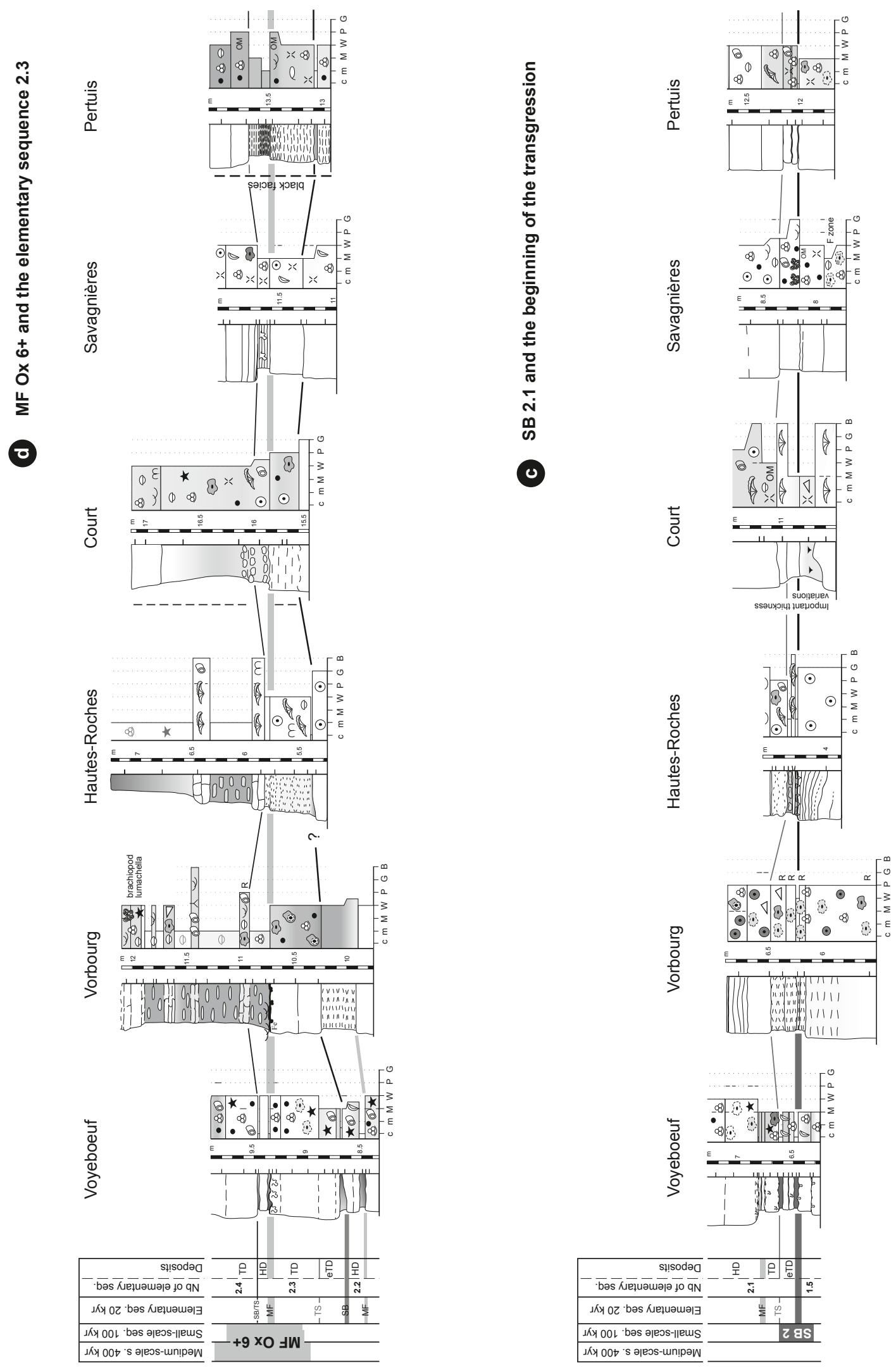

Fig. 12. Detailed correlation of elementary sequences around major sequential limits. (a) SB Ox6+, which at the same time contains the sequence boundaries of 400-, 100-, and 20-kyr sequences; (b) MF 1.3 on the 100- and 20-kyr level. 

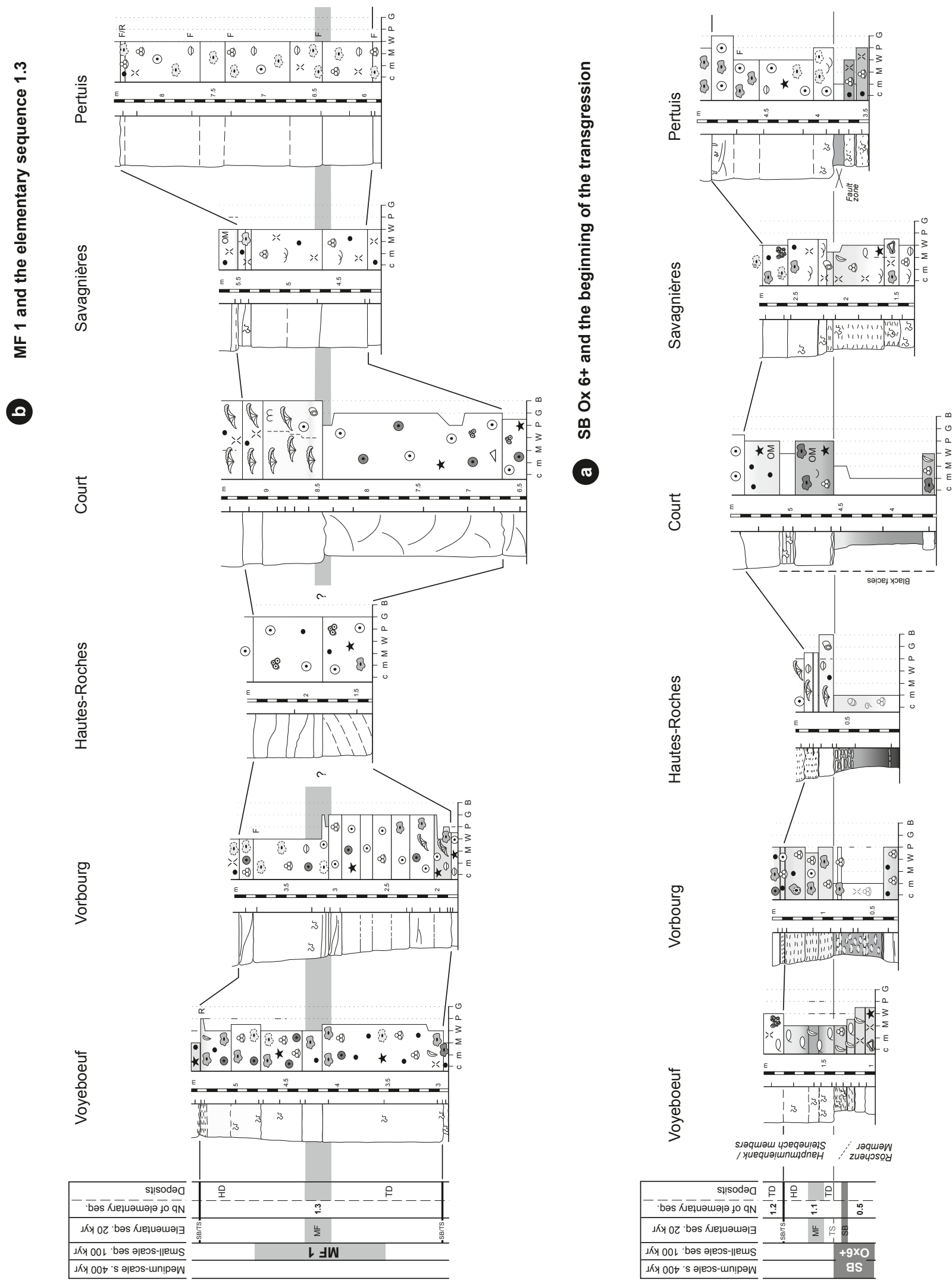

Fig. 12. (Continued). (c) SB 2.1 on the 100- and 20-kyr level; (d) MF Ox6+ on the 400-, 100-, and 20-kyr level. For symbols, refer to Figure 9. 
form positions and particularly in the Pertuis section (Fig. 13b). Inversely, protected lagoonal environments abound in Voyeboeuf, in the most "proximal" platform position. However, at a smaller scale, within elementary and small-scale sequences, the facies distribution is patchy and thus implies at least partly the influence of platform morphology. The latter is variable (a) Facies distribution
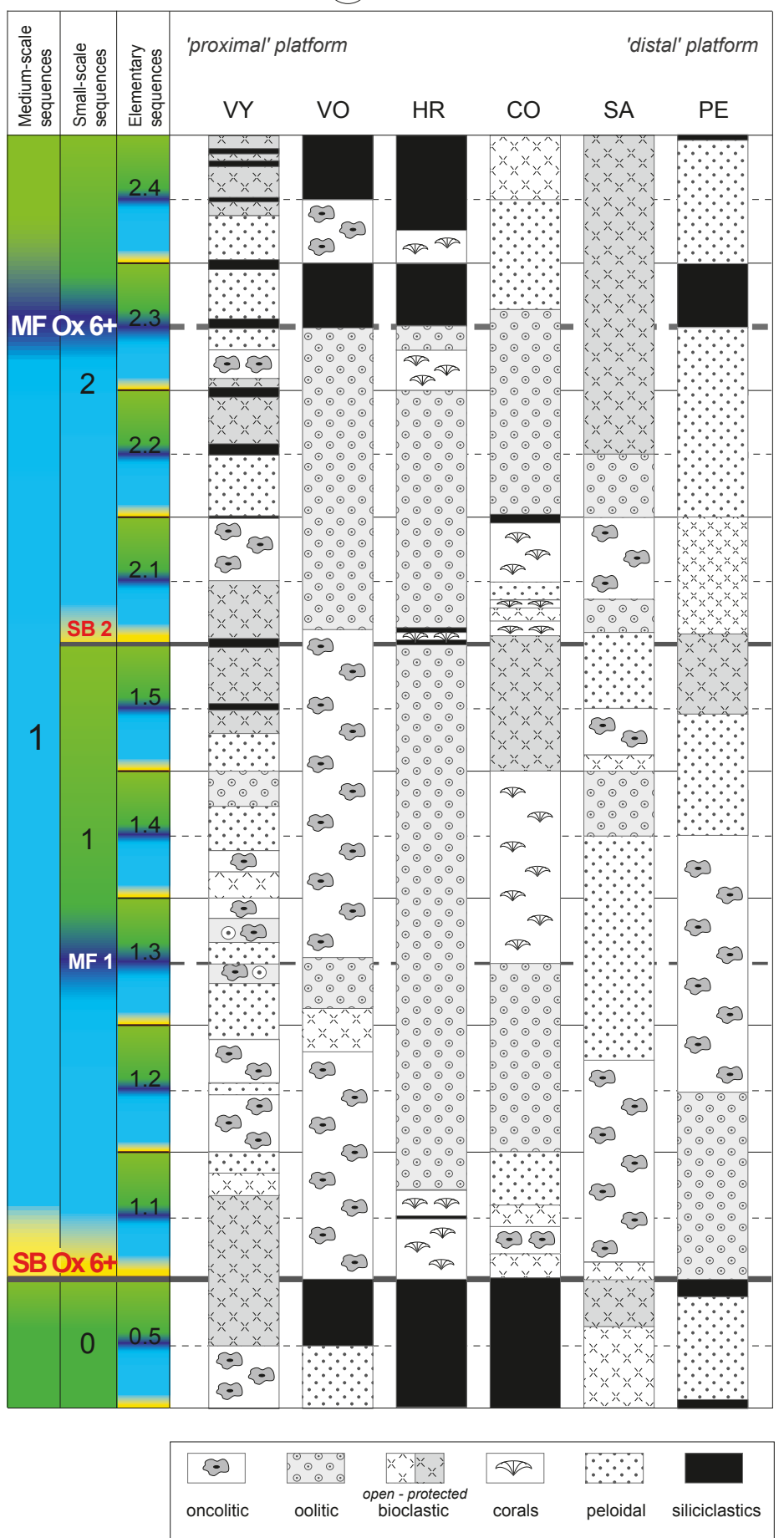

(b) Distribution of depositional environments

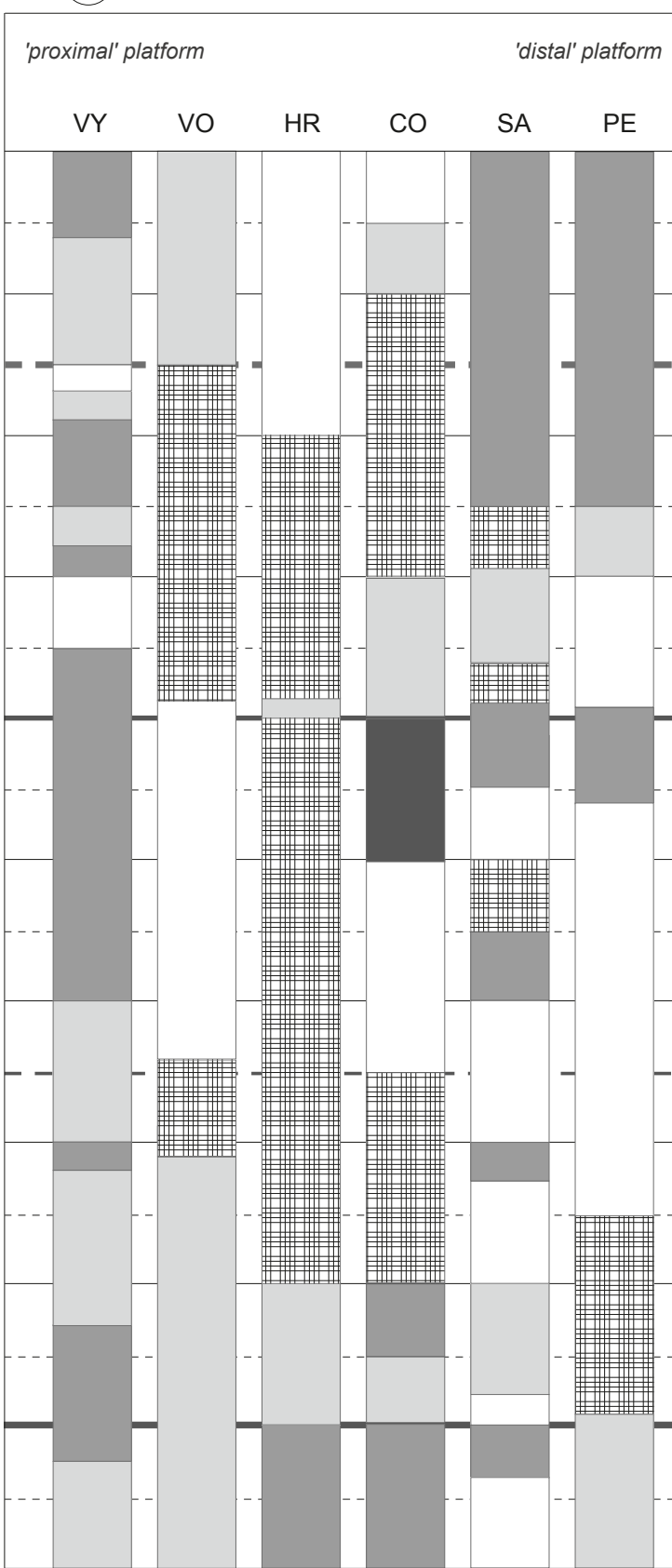

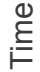

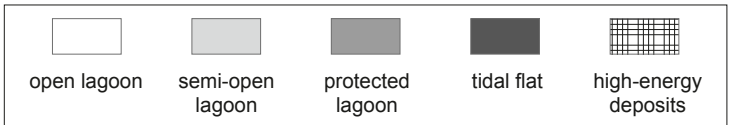

Fig. 13. Time-space diagram illustrating the distribution of major facies and depositional environments of the six sections studied across the Swiss Jura platform within one and a half small-scale sequences (Védrine 2007). The sequence boundaries of the small-scale and elementary sequences are considered as time lines. For discussion refer to text. 
d MF Ox6+

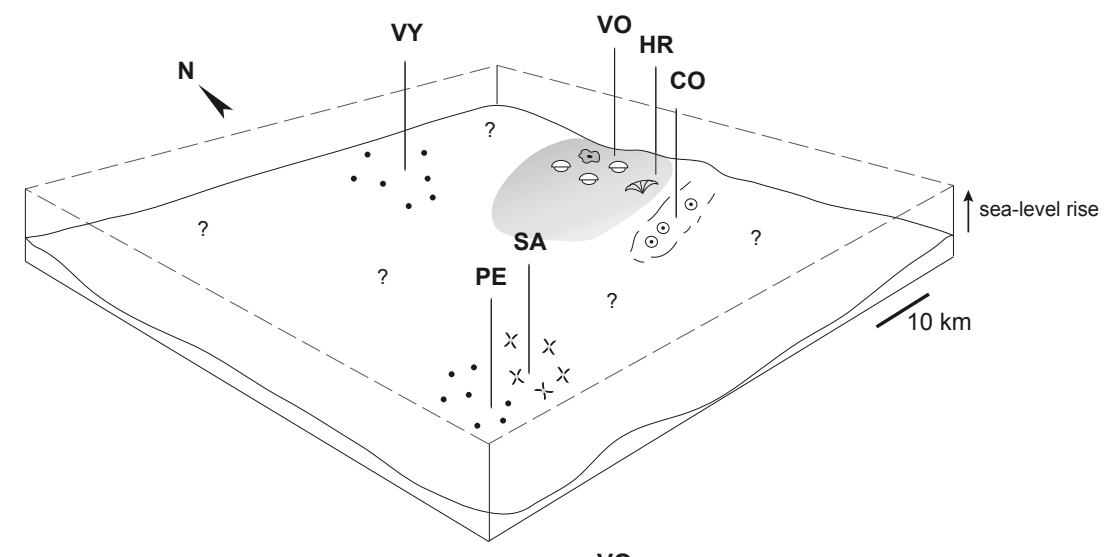

C SB 2

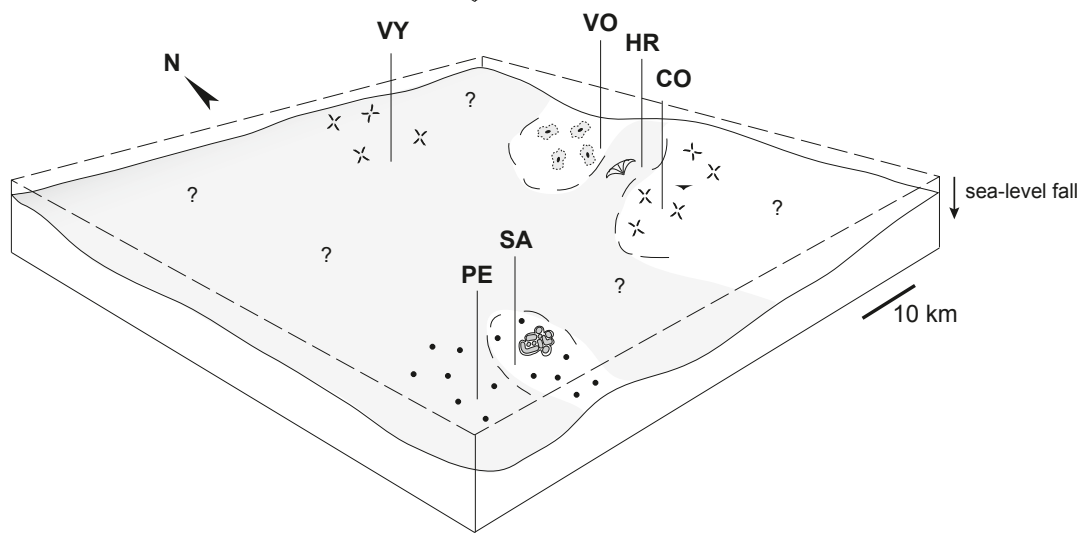

(b) MF 1
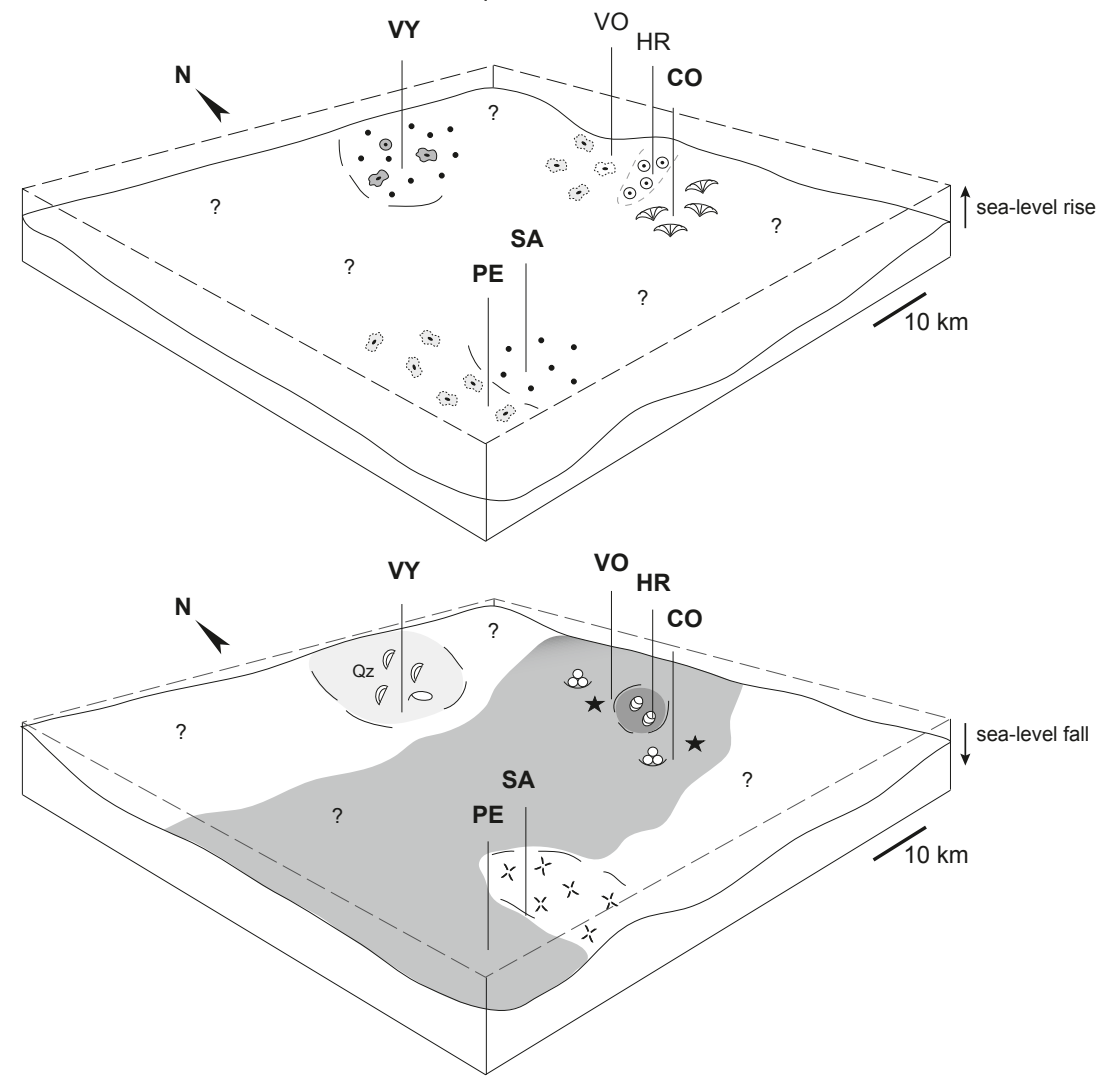

(a) $\mathrm{SBO} 6+$

Fig. 14. Spatial reconstruction of the Swiss Jura platform at selected time intervals: (a) SB Ox6+, (b) MF 1.3, (c) SB 2.1, (d) MF Ox6+. Symbols are as in Figure 9. CO: Court section; HR: Hautes-Roches; PE: Pertuis; SA: Savagnières; VO: Vorbourg; VY: Voyeboeuf. 
and was created by differential subsidence (Wetzel et al. 2003; Allenbach 2001). The sediment accumulation (carbonates and siliciclastics) further accentuated or attenuated the relief. For example, during periods of coral reef growth and ooid production, equivalent to high carbonate productivity, the irregular morphology was enhanced. Reefs formed on structural highs along the platform margin but could later find themselves in rapidly subsiding areas due to tectonic inversion. Ooid bars not only occurred on the platform margin but also in the platform interior where morphological highs created favourable conditions. Locally, wide channels brought relatively open-marine conditions into more central platform positions, generating high-energy depositional environments. Behind reefs and bars, lagoons were isolated or protected from open-marine influence and from wave or current energy (Fig. 8; Hug 2003; Strasser \& Védrine 2009). Lagoonal facies with oncoids show a patchy distribution. No systematic relationship with the other facies is recognizable, although the most persistent oncoid-rich lagoons appear to be situated preferentially on the inner platform when compared to ooid bars and coral reefs.

The spatial facies distribution is monitored for different selected time intervals corresponding to major sequential limits of medium-scale and small-scale sequences (Fig. 14; compare also with Fig. 12). At the SB Ox6+, a major sea-level fall caused the invasion of the platform by siliciclastics (Fig. 14a). At this time, the Voyeboeuf and Savagnières sections were dominated by bioclasts and do not present marls, suggesting that these locations were topographic highs. Then the transgression began and led to the disappearance of siliciclastics. The increase of accommodation favoured homogenization and diversification of lagoonal facies and marks the small-scale MF 1 (Fig. 14b). The Voyeboeuf and Savagnières sections still present similar facies (micrite-dominated oncoid and peloidal facies). The Vorbourg and Pertuis sections show Bacinella-Lithocodium oncoid facies. High-energy conditions dominated at Hautes-Roches, and a large coral patch-reef developed at Court. Then, sea level fell again. At this time, minor inputs of siliciclastics are noticed especially in the Hautes-Roches and Voyeboeuf sections (Fig. 14c), birdseyes representing tidal flat facies are observed in the Court section, a serpulid-rich level occurs in the Savagnières section, and peloidal facies dominates in the Pertuis section. Finally, sea level rose again, creating an increase of accommodation (around the MF Ox6+; Fig. 14d). Peloid- and bioclast-rich facies formed at Voyeboeuf, Pertuis, and Savagnières. As for MF 1, the Court and Hautes-Roches sections present ooid bars and coral patch-reefs while the Vorbourg section is rich in brachiopods and micrite-dominated oncoids.

\section{Conclusions}

Detailed facies and microfacies analysis of six shallow carbonate platform sections in the Swiss Jura Mountains, coupled with sequence- and cyclostratigraphic analysis, allows interpreting the platform evolution through time and space during a transgressive interval dated of the beginning of the Bimammatum zone (Late Oxfordian). Facies and microfacies as well as the floral and faunal assemblages point to various depositional environments: tidal flats, protected, semi-protected, and open lagoons, high-energy ooid bars, and coral patch reefs. Vertical facies evolution implies high-frequency palaeoenvironmental changes, which were related to sea-level and climate variations. The similar stacking pattern of depositional sequences in all sections suggests a major control on sedimentation by a common external factor such as eustatic sea-level changes. In the studied interval, small-scale sequences are commonly composed of five elementary sequences. This hierarchy and independent biochronostratigraphic time control suggest that these sequences formed in tune with insolation changes controlled by the astronomical parameters of the Earth's orbit (Milankovitch cycles): the small-scale sequences correspond to the first eccentricity cycle of $100 \mathrm{kyr}$, the elementary sequences to the precession cycle of $20 \mathrm{kyr}$. The studied interval thus covers $180 \mathrm{kyr}$. The best-fit correlation of the sections at the level of elementary and small-scale sequences helps monitoring the vertical facies changes corresponding to the general evolution of the depositional environments but also reveals important lateral facies changes, which created a complex facies mosaic on the Swiss Jura platform. Besides the high-frequency sea-level fluctuations, platform morphology also played an important role in the patchy distribution of facies. This variable morphology was created by differential subsidence of tectonic blocks and by differential sediment accumulation. Increased carbonate productivity in favourable positions further enhanced the relief. Coral reefs and ooid shoals developed preferentially on morphological highs, while siliciclastics were distributed through depressions. The reconstruction of facies distribution with a time resolution of $20 \mathrm{kyr}$ gives a dynamic picture of the platform evolution, highlighting the variations through time of platform morphology and siliciclastic distribution as well as the complexity of the juxtaposed depositional environments. Such platform reconstructions in time and space are the starting point for interpreting and quantifying the controlling factors such as eustatic sealevel fluctuations, climate changes, differential subsidence, and ecology of the carbonate-producing organisms.

\section{Acknowledgements}

We would like to thank Claude Colombié and Wolfgang Hug for their constructive reviews. This research has been accomplished in the frame of project 20-109214.05 of the Swiss National Science Foundation. The financial support is gratefully acknowledged.

\section{REFERENCES}

Allenbach, R.P.2001: Synsedimentary tectonics in an epicontinental sea: a new interpretation of the Oxfordian basins of northern Switzerland. Eclogae Geologicae Helvetiae 94, 265-287.

Allenbach, R.P. 2002: The ups and downs of "tectonic quiescence" - recognizing differential subsidence in the epicontinental sea of the Oxfordian in the Swiss Jura Mountains. Sedimentary Geology 150, 323-342.

Berger, A., Loutre, M.F. \& Dehant, V. 1989: Astronomical frequencies for preQuaternary paleoclimate studies. Terra Nova 1, 474-479.

268 S. Védrine \& A. Strasser 
Bolliger, W. \& Burri, P. 1967: Versuch einer Zeitkorrelation zwischen Plattformcarbonaten und tiefermarinen Sedimenten mit Hilfe von QuarzFeldspat-Schüttungen (mittlerer Malm des Schweizer Jura). Eclogae Geologicae Helvetiae 60, 491-507.

Bolliger,W. \& Burri, P. 1970: Sedimentologie von Schelf-Carbonaten und Beckenablagerungen im Oxfordien des zentralen Schweizer Jura. Beiträge zur Geologischen Karte der Schweiz N.F. 140, 96 pp.

Brasier, M.D. 1995: Fossil indicators of nutrient level. 1: Eutrophication and climate. Marine palaeoenvironmental analysis from fossils. Geological Society of London, Special Publication 83,113-132.

Colombié, C. \& Strasser, A. 2005: Facies, cycles, and controls on the evolution of a keep-up carbonate platform (Kimmeridgian, Swiss Jura). Sedimentology 52,1207-1227.

Dercourt, J., Ricou, L.E. \& Vrielynck, B. (Eds.) 1993: Atlas Tethys, Palaeoenvironmental Maps. CCGM, Paris.

Dupraz, C. 1999: Paléontologie, paléoécologie et évolution des faciès récifaux de l'Oxfordien moyen-supérieur (Jura suisse et français). GeoFocus 2, Fribourg, $200 \mathrm{pp}$.

Dupraz, C. \& Strasser, A. 1999: Microbialites and micro-encrusters in shallow coral bioherms (Middle to Late Oxfordian, Swiss Jura Mountains). Facies 40,101-130.

Elliott, G.F. 1956: Further records of fossil calcareous algae from the Middle East. Micropaleontology 2,327-334.

Enay, R., Contini, D. \& Boullier,A. 1988: Le Séquanien-type de FrancheComté (Oxfordien supérieur): datations et corrélations nouvelles, conséquences sur la paléogéographie et l'évolution du Jura et régions voisines. Eclogae Geologicae Helvetiae 81(2), 295-363.

Flügel, E. 2004: Microfacies of carbonate rocks. Springer, 976 pp.

Frakes, L.A., Francis, J.E. \& Syktus, J.I. 1992: Climate modes of the Phanerozoic. Cambridge University Press, 270 pp.

Gradstein, F.M., Agterberg, F.P., Ogg, J.G., Hardenbol, J., van Veen, P., Thierry, J. \& Huang, Z., 1995: A Triassic, Jurassic and Cretaceous time scale. In: Berggren, W.A., Kent, D.V., Aubry, M.P. \& Hardenbol, J. (Eds.): Geochronology, Time Scales and Global Stratigraphic Correlation. SEPM Special Publication 54, 95-126.

Gygi, R.A. 1969: Zur Stratigraphie der Oxford-Stufe (oberes Jura-System) der Nordschweiz und des süddeutschen Grenzgebietes. Beiträge zur Geologischen Karte der Schweiz N.F. 136, 123 pp.

Gygi, R.A. 1986: Eustatic sea-level changes of the Oxfordian (Late Jurassic) and their effect documented in sediments and fossil assemblages of an epicontinental sea. Eclogae Geologicae Helvetiae 79, 455-491.

Gygi, R.A. 1992: Structure, pattern of distribution and paleobathymetry of late Jurassic microbialites (stromatolites and oncoids) in northern Switzerland. Eclogae Geologicae Helvetiae 85, 799-824.

Gygi, R.A. 1995: Datierung von Seichtwassersedimenten des Späten Jura in der Nordwestschweiz mit Ammoniten. Eclogae Geologicae Helvetiae 88,1-58.

Gygi, R.A. 2000a: Annotated index of lithostratigraphic units currently used in the Upper Jurassic of northern Switzerland. Eclogae Geologicae Helvetiae $93,125-146$.

Gygi, R.A.2000b: Integrated stratigraphy of the Oxfordian and Kimmeridgian (Late Jurassic) in northern Switzerland and adjacent southern Germany. Mémoire de l'Académie Suisse des Sciences Naturelles 104, 151 pp.

Gygi, R.A. \& Persoz, F. 1986: Mineralostratigraphy, litho- and biostratigraphy combined in correlation of the Oxfordian (Late Jurassic) formations of the Swiss Jura range. Eclogae Geologicae Helvetiae 79, 385-454.

Hallam, A. 1984: Continental humid and arid zones during the Jurassic and Cretaceous. Palaeogeography, Palaeoclimatology, Palaeoecology 47, 195-223.

Hallam, A. 1985: A review of Mesozoic climates. Journal of the Geological Society, London, 142, 433-445.

Hardenbol, J., Thierry, J., Farley, M.B., Jacquin, T., de Graciansky, P.-C. \& Vail, P.R. 1998: Jurassic sequence chronostratigraphy. In: de Graciansky, P.-C., Hardenbol, J., Jacquin, T. \& Vail, P.R. (Eds.): Mesozoic and Cenozoic sequence stratigraphy of European Basins. SEPM Special Publication 60, chart.

Hug, W. 2003: Sequenzielle Faziesentwicklung der Karbonatplattform des Schweizer Jura im Späten Oxford und frühesten Kimmeridge. GeoFocus 7, Fribourg, 156 pp.
IPCC 2007: Fourth Assessment Report - Climate Change 2007. http://www. ipcc.ch.

Merian, P. 1821: Beiträge zur Geognosie, Bd 1. Übersicht der Beschaffenheit der Gebirgsbildungen in den Umgebungen von Basel. Basel, Schweighausersche Buchhandlung, $156 \mathrm{pp}$.

Meyer,R.K.F.\&Schmidt-Kaler,H.1990:Paläogeographie undSchwammriffentwicklung des süddeutschen Malm - ein Überblick. Facies 23, 175-184.

Moore, G.T., Hayashida, D.N., Ross, C.A. \& Jacobson, S.R. 1992: Paleoclimate of the Kimmeridgian/Tithonian (Late Jurassic) world: I. Results using a general circulation model. Palaeogeography, Palaeoclimatology, Palaeoecology 93, 113-150.

Parrish, J.T. 1993: Climate of the supercontinent Pangea. Journal of Geology 101, 215-233.

Persoz, F. \& Remane, J. 1976: Minéralogie et géochimie des formations à la limite Jurassique-Crétacé dans le Jura et le bassin vocontien. Eclogae Geologicae Helvetiae 69(1), 1-38.

Pittet, B. 1996: Contrôles climatiques, eustatiques et tectoniques sur des systèmes mixtes carbonates-siliciclastiques de plate-forme: exemples de l'Oxfordien (Jura suisse, Normandie, Espagne). Unpublished PhD thesis, University of Fribourg, Switzerland, 258 pp.

Radoicic, R. 1959: Some problematic microfossils from the Dinarian Cretaceous. Bulletin du Service Géologique et Géophysique de la R.P. Serbie 17, 87-92.

Rameil, N. 2005: Carbonate sedimentology, sequence stratigraphy, and cyclostratigraphy of the Tithonian in the Swiss and French Jura mountains: a high-resolution record of changes in sea-level and climate. GeoFocus $13,246 \mathrm{pp}$.

Samankassou, E., Strasser, A., Di Gioia, E., Rauber, G. \& Dupraz, C. 2003: High-resolution record of lateral facies variations on a shallow carbonate platform (Upper Oxfordian, Swiss Jura Mountains). Eclogae Geologicae Helvetiae 96, 425-440.

Strasser, A. 1986: Ooids in Purbeck limestones (lowermost Cretaceous) of the Swiss and French Jura. Sedimentology 33, 711-727.

Strasser, A. 1991: Lagoonal-peritidal sequences in carbonate environments: Autocyclic and allocyclic processes. In: Einsele, G., Ricken, W. \& Seilacher, A. (Eds.): Cycles and events in stratigraphy. Springer, 709721.

Strasser, A. 2007: Astronomical time scale for the Swiss and French Jura Mountains (Middle Oxfordian to Late Kimmeridgian). Swiss Journal of Geosciences 100, 407-429.

Strasser, A., Aurell, M., Badenas, B., Melendez, G. \& Tomas, S. 2005: From platform to basin to swell: orbital control on sedimentary sequences in the Oxfordian, Spain. Terra Nova 17, 407-413.

Strasser, A., Hillgärtner, H., Hug, W. \& Pittet, B. 2000: Third-order depositional sequences reflecting Milankovitch cyclicity. Terra Nova 12,303-311.

Strasser, A., Pittet, B., Hillgärtner, H. \& Pasquier, J.B. 1999: Depositional sequences in shallow carbonate-dominated sedimentary systems: concepts for a high-resolution analysis. Sedimentary Geology 128, 201-221.

Strasser, A. \& Védrine, S. 2009: Controls on facies mosaics of carbonate platforms: a case of study from the Oxfordian of the Swiss Jura. In: Swart, P.K., Eberli, G.P. \& McKenzie (Eds.): J.A., Perspectives in Sedimentary Geology. International Association of Sedimentologists, Special Publication 41, 199-213.

Thierry, J. et al. (41 co-authors) 2000: Map 10, Early Kimmeridgian. In: Dercourt J., Gaetani M. et al. (Eds.) Atlas Peri-Tethys, Palaeogeographical Maps. CCGM/CGMW, Paris.

Vail, P.R., Audemard, F., Bowman, S.A., Eisner, P.N. \& Perez-Cruz, C. 1991: The stratigraphic signatures of tectonics, eustasy and sedimentology - an overview. In: Einsele, G., Ricken, W. \& Seilacher, A. (Eds.): Cycles and events in stratigraphy. Springer, Heidelberg, 617-659.

Vail, P.R., Mitchum, R.M. \& Thompson, D.B. 1977: Seismic stratigraphy and global changes of sea level, part 3: Relative changes of sea level from coastal onlap. In: Payton, C.E. (Ed.): Seismic stratigraphy - applications to hydrocarbon exploration. American Association of Petroleum Geologists Memoir 26, 63-81.

Védrine, S. 2007: High-frequency palaeoenvironmental changes in mixed carbonate-siliciclastic sedimentary systems (Late Oxfordian, Switzerland, France, and southern Germany). GeoFocus 19, Fribourg, 216 pp. 
Védrine, S., Strasser, A. \& Hug, W. 2007: Oncoid growth and distribution controlled by sea level and climate. Facies 53, 535-552.

Wetzel, A., Allenbach, R. \& Allia, V. 2003: Reactivated basement structures affecting the sedimentary facies in a tectonically "quiescent" epicontinental basin: an example from NW Switzerland. Sedimentary Geology $157,153-172$.

Wignall, P.B. \& Ruffell, A.H. 1990: The influence of a sudden climatic change on marine deposition in the Kimmeridgian of northwest Europe. Journal of the Geological Society, London, 147, 365-371.

Wright, V.P. \& Burgess, P.M. 2005: The carbonate factory continuum, facies mosaics and microfacies: An appraisal of some of the key concepts underpinning carbonate sedimentology. Facies 51, 17-23.
Ziegler, M.A. 1962: Beiträge zur Kenntnis des unteren Malm im zentralen Schweizer Jura. Unpublished PhD thesis, University of Zürich, Switzerland, $51 \mathrm{pp}$.

Ziegler, P.A. 1988: Evolution of the Arctic-North Atlantic and the western Tethys. American Association of Petroleum Geologists Memoir 43 , 198 pp.

Manuscript received January 15, 2008

Revision accepted June 2,2009

Published Online first August 28, 2009

Editorial Handling: A. Wetzel \& S. Bucher 